SOEP

SOEPpapers

SOEPpapers
on Multidisciplinary Panel Data Research

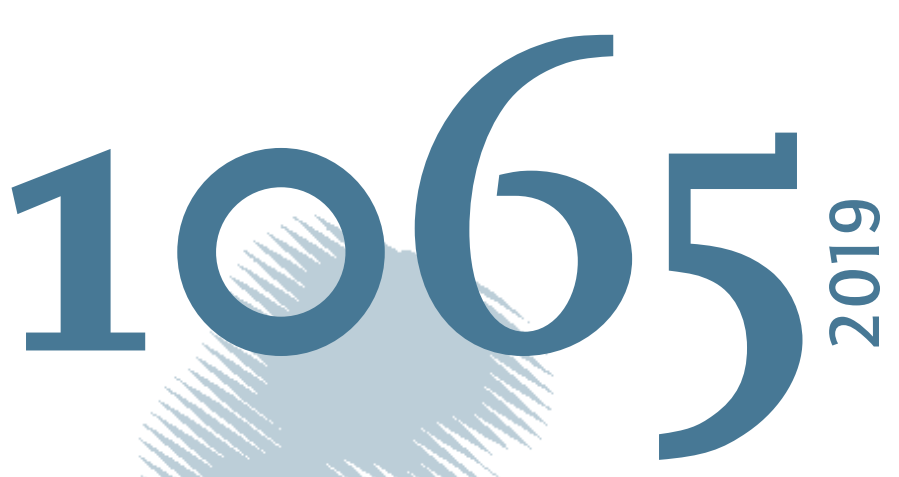

\title{
Do(n't) Worry, It's Temporary: The Effects of Fixed-Term Employment on Affective Well-Being
}


This series presents research findings based either directly on data from the German SocioEconomic Panel (SOEP) or using SOEP data as part of an internationally comparable data set (e.g. CNEF, ECHP, LIS, LWS, CHER/PACO). SOEP is a truly multidisciplinary household panel study covering a wide range of social and behavioral sciences: economics, sociology, psychology, survey methodology, econometrics and applied statistics, educational science, political science, public health, behavioral genetics, demography, geography, and sport science.

The decision to publish a submission in SOEPpapers is made by a board of editors chosen by the DIW Berlin to represent the wide range of disciplines covered by SOEP. There is no external referee process and papers are either accepted or rejected without revision. Papers appear in this series as works in progress and may also appear elsewhere. They often represent preliminary studies and are circulated to encourage discussion. Citation of such a paper should account for its provisional character. A revised version may be requested from the author directly.

Any opinions expressed in this series are those of the author(s) and not those of DIW Berlin. Research disseminated by DIW Berlin may include views on public policy issues, but the institute itself takes no institutional policy positions.

The SOEPpapers are available at http://www.diw.de/soeppapers

\section{Editors:}

Jan Goebel (Spatial Economics)

Stefan Liebig (Sociology)

David Richter (Psychology)

Carsten Schröder (Public Economics)

Jürgen Schupp (Sociology)

Sabine Zinn (Statistics)

Conchita D'Ambrosio (Public Economics, DIW Research Fellow)

Denis Gerstorf (Psychology, DIW Research Fellow)

Katharina Wrohlich (Gender Studies)

Martin Kroh (Political Science, Survey Methodology)

Jörg-Peter Schräpler (Survey Methodology, DIW Research Fellow)

Thomas Siedler (Empirical Economics, DIW Research Fellow)

C. Katharina Spieß (Education and Family Economics)

Gert G. Wagner (Social Sciences)

ISSN: 1864-6689 (online)

German Socio-Economic Panel (SOEP)

DIW Berlin

Mohrenstrasse 58

10117 Berlin, Germany

Contact: soeppapers@diw.de

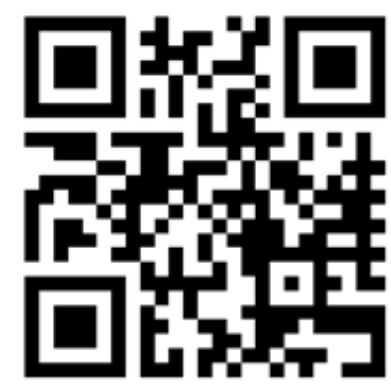




\title{
Do(n't) Worry, It's Temporary: The Effects of Fixed-Term Employment on Affective Well-Being
}

\author{
Paul Schumann ${ }^{1} \&$ Prof. Dr. Lars Kuchinke ${ }^{2}$
}

\section{Author affiliations:}

1 Department of Psychology, Humboldt University of Berlin, Berlin, Germany 2 Department of Psychology, International Psychoanalytic University Berlin, Berlin Germany

This manuscript is published as:

Paul Schumann and Lars Kuchinke (2019). Do(n't) Worry, It's Temporary: The Effects of Fixed-Term Employment on Affective Well-Being. In: Journal of Happiness Studies (online first). https://doi.org/10.1007/s10902-019-00194-8

First published online: October 25, 2019

(C) 2019 The Authors. Journal of Happiness Studies published by Springer Netherlands

Corresponding Author:

Paul Schumann

Humboldt University of Berlin

Faculty of Life Sciences

Department of Psychology

Unter den Linden 6, 10099 Berlin

Phone: +4915738997507

E-Mail: sumannpa@hu-berlin.de 


\section{Abstract}

This paper examines the impact of fixed-term employment on the affective and cognitive well-being of employees operationalized by the subjective frequency of the basic emotions of happiness, sadness, fear and anger as well as life satisfaction. Longitudinal effects were analysed across 10 waves of sampling from the Socio-Economic Panel (SOEP), an annual representative survey in Germany. Random effects within between model (REWB) analyses were applied to examine differences between fixed-term and permanent workers as well as within effects of a change of contract type. In addition, the impact of the direction of contract type change was evaluated by examining subsamples with changes from fixed-term to permanent and vice versa. The results suggest that fixed-term employees' affective wellbeing is lower, while cognitive well-being (or happiness) is hardly affected. A change from permanent to fixed-term contracts is associated with higher frequencies of self-reported fear and sadness experiences, while a change in the opposite direction results in lower frequencies. In addition, life satisfaction was only found to increase with the change from fixed-term to permanent employment. While the effect on fear is masked by job security, acting as a mediating factor, the effect on sadness remains significant when the model is controlled for job security. Thus, by treating cognitive and affective well-being as separate constructs this study provides new insights into the psychological costs of fixed-term contracts and reveals the strong impact of fixed-term employment on self-reported experiences of sadness.

Keywords: fixed-term employment, affective well-being, job security, job change, cognitive well-being, life satisfaction, hybrid models.

\section{Introduction}

In recent years, political leaders in many countries have continued to call for and to implement labour market reforms to grant more flexible options for companies as well as for employees, leading to the erosion of traditional full-time, permanent employment. For example, the number of atypical employees in the labour market in Germany has been growing for the past 15 years (Hans-Böckler-Stiftung, 2017). At the same time, every twelfth employment contract in Germany is a fixed-term contract (Deutscher Bundestag, 2017). Similar developments can be observed in many other EU countries as well as in the United States (Kalleberg, 2011; Scherer, 2009; Vacas-Soriano, 2015).

Such market place flexibility and the corresponding increase of fixed-term employment are often regarded as the key to reducing unemployment (but see Odenthal, 2017). Thus, 
fixed-term employment might have both positive and negative effects on workers depending on their personal preferences. The increased flexibility, alongside a continuous change of work and some other aspects of the daily experience related to fixed-term work, could be favoured by some employees (Dawson, Veliziotis \& Hopkins, 2017). However, only around 6.5\% of temporary employees in Germany have voluntarily opted for a contract with a limited duration (Crößmann, Günther \& Marder-Puch, 2017). Still, this type of flexibility might have consequences when looking at the potential psychological costs.

Different labour market theories, for example the Flexible Firm Model (Atkinson, 1984), Human Capital Theory (Becker, 1993), or Segmentation Theory (Amuedo-Dorantes, 2000), suggest that fixed-term workers are considered as peripheral workers (for a review see De Cuyper, De Jong, De Witte, Isaksson, Rigotti, \& Schalk, 2008). As a result, it is assumed that employers are unlikely to invest in organizational commitment and loyalty towards the company (Boyce, Ryan, Imus \& Morgeson, 2007; Zeytinoglu \& Cooke, 2005; Zeytinoglu \& Muteshi, 2000). Moderated by an increase of job strain, this may lead to a reduction of subjective well-being (De Witte \& Näswall, 2003). In addition, fixed-term work is associated with efforts aimed at staying employed and with the continuous search for new (and likely permanent) employment, as well as with the desire to maintain a positive employer assessment of work performance. As a consequence, the employees experience lower levels of job security as well as lower support levels at work (Scherer, 2009). Such stressors are known to contribute to an overall lower self-reported health and lower life satisfaction (De Cuyper et al., 2008; Voßemer, Gebel, Täht, Unt, Högberg \& Strandh, 2018).

On the other hand, fixed-term employment could be seen as a bridge towards permanent employment (Booth, Francesconi \& Frank, 2002; Scherer, 2009; Rigotti \& Mohr, 2017; for a review see De Cuyper et al., 2008) with the accompanying positive effects on motivation and expectation for fixed-term workers.

Still, the literature on these psychological effects provides mixed results, in particular when it comes to the consequences of fixed-term work on mental health and psychological well-being. Atypical work and fixed-term employment reduce job satisfaction (Kröll \& Nüesch, 2017), a relationship which is is most likely mediated by subjective job security (Giesselmann, Staneva, Schupp \& Richter, 2017; De Cuyper \& De Witte, 2006; Jahn, 2015). Fixed-term employment is known to be associated with lower job security (Booth et al., 2002; Brehmer \& Seifert, 2008; Giesecke, 2009; Kalleberg, 2011). Dawson and colleagues (2017) provided detailed evidence that job security mediates the overall life satisfaction of fixed-term workers. Accordingly, recent meta-analyses found that fixed-term workers have fewer absences from 
work and report psychological complaints less frequently than permanent workers (AmlingerChatterjee, 2016; Hünefeld, 2016), an effect that has been related to differences in job security between permanent and fixed-term workers (De Cuyper et al., 2008). In sum, these studies revealed heterogenous results on this topic, with sometimes better and sometimes poorer mental health and psychological well-being associated with fixed-term contracts compared to permanent contracts (for a review see De Cuyper et al., 2008; Hünefeld \& Köper, 2016; see also Richardson, Lester and Zhang, 2012, revealing no significant relationship between fixedterm employment and mental health status).

The subjective well-being of temporary workers has been examined in cross-sectional and longitudinal studies (e.g., Bardasi \& Francesconi, 2004; De Cuyper \& De Witte, 2006; Dawson et al., 2017), both of which focused mainly on the cognitive aspects of subjective wellbeing (i.e. life satisfaction). While cross-sectional studies have shown significant differences in life satisfaction between fixed-term and permanent employees (Silla, Gracia \& Peiró, 2005; Virtanen, Kivimäki, Joensuu, Virtanen \& Vahtera, 2005), longitudinal analysis (that allows the examination of causal relations) has only shown weak effects (Dawson, et al., 2017) or no effects at all (Bardasi \& Francesconi, 2004; De Cuyper \& De Witte, 2006). As demonstrated above, these inconsequential effects might be explained by uncontrolled job security.

Furthermore, Chadi \& Hetschko (2015) discussed a likely role of job change in explaining effects of fixed-term work on job satisfaction. When the start of a new temporary employment is accompanied by an overall positive evaluation by the employee, this might neutralize likely negative effects of fixed-term contracts on job satisfaction. Although no direct transition exists from the somewhat immediate effects on job satisfaction towards long-term effects on life satisfaction, some authors have discussed that not controlling for the effects of job change could possibly lead to biased results (Dawson et al., 2017; De Cuyper, Notelaers \& De Witte, 2009).

But there might also be a measurement effect for this construct. Life satisfaction is a global judgment of the quality of a person's life (Diener, 1984). It requires cognitive processing because individuals need to examine different conditions in their lives, weigh their importance and then make an evaluation on a single scale (Diener, Scollon \& Lucas, 2004). An advantage of life satisfaction as a psychological construct is that it captures a global sense of well-being from the respondent's own perspective (Diener et al., 2004). On the other hand, such a single, generalized measurement is prone to different biases. It has been shown that "irrelevant" information, such as weather or mood, also affect life satisfaction judgments (Schwarz \& Clore ,1983). Still, the measurement of general life satisfaction shows high reliability (Schilling, 2006; 
Schimmack \& Lucas, 2006) and validity (Schimmack \& Oishi 2005) and is used much more frequently than affective well-being to study subjective well-being (e.g., Ehrhard, Saris \& Veenhoven, 2000; Fujita \& Diener, 2005; Winkelmann \& Winkelmann, 1998).

However, the present study is aimed at investigating the affective components of wellbeing of temporary workers in addition to its cognitive parts. Some studies define affective wellbeing as a part of mental or psychological health (Hünefeld \& Köper, 2016), because psychological distress and well-being can be measured using the same medical diagnosis tools (e.g. GHQ; Goldberg \& Hillier, 1979). By contrast, newly developed instruments for measuring affective well-being primarily capture everyday experiences rather than pathological or non-pathological cases (von Scheve, Esche, \& Schupp, 2017). Thus, emotions or feelings that directly contribute to affective well-being and rather fluctuate from day to day (Sumner, 1996) are the focus of present research. Most researchers agree that affective and cognitive well-being are interrelated (Schimmack, 2008, Kuppens, Realo \& Diener, 2008), but that each component provides unique information about the subjective quality of a person's life (Diener et al., 2004). Contrary to the cognitive components of well-being, affective well-being reflects a person's ongoing evaluation of the conditions in his or her life (Diener et al., 2004) and is understood as a balance between individual happiness and uneasiness (Schimmack, Schupp \& Wagner, 2008).

Of interest is that the German Socio-Economic Panel (SOEP), a longitudinal and representative national survey, recently decided to include both types of measurement, cognitive and affective well-being, as sub-components of subjective well-being (Schimmack et al., 2008; cf. Sumner, 1996). Affective well-being in the SOEP is captured by the frequency of fear, sadness, anger and happiness experienced during the previous four weeks. Thus, the SOEP provides a unique opportunity to compare the effects of fixed-term contracts on affective and cognitive well-being from a representative panel based on German household data of up to 30,000 participants, which will form the basis of the present examinations. The use of this multi-dimensional construct with its measurement of four different emotions can be expected to reveal another more detailed insight into the daily experience of fixed-term employees compared to the unidimensional measuring of general life satisfaction. Emotions are shortlived reactions that are usually caused by specific events or other external stimuli (Frijda, 1999). This makes a frequency measurement particularly interesting for the present study, since the working conditions seem able to evoke different (positive and/or negative) emotions at different rates of frequency. Von Scheve and colleagues (2017) also suggest that focusing on specific emotions could allow a more likely prediction of consequences, since those would often go hand in hand with specific tendencies and actions. 
Even though affective and cognitive well-being are interrelated, they can be treated as separate constructs (see Diener et al., 2004). This allows for the possibility that, for example, an individual could be satisfied with his or her life, and yet still experiences a lot of unpleasant emotions. So, in theory it's possible that fixed-term employment impacts affective well-being, even though cognitive well-being may not be not affected. In particular, temporary work is often accompanied by worse working conditions and notice periods (Booth et al., 2002; Brehmer \& Seifert, 2008), which both can be expected to contribute to negative emotional experiences which are not captured by measures of life satisfaction. Of further note are the different time scales of affective and cognitive well-being. While affective well-being measures immediate and ongoing affective responses, it has been suggested that changes in contract type might have somewhat long-term effects on well-being (Sverke, Hellgren \& Näswall, 2002). Akin to what is reported in life satisfaction literature (Dawson et al., 2017), job security and job change might also explain parts of the effects of fixed-term employment on affective well-being. Thus, an evaluation of effects on affective well-being also needs to consider (or control for) the likely mediating effects of job security and the moderating role of job change.

In sum, previous literature reported only weak relationships between fixed-term employment and cognitive well-being when estimating within effects based on longitudinal data. Most studies on this topic have relied on fixed effects (FE) regressions. FE models control for time-constant unobserved heterogeneity (e.g., personality traits) by relying solely on withinperson variation. This comes with the downside of a lower statistical power since there must be a change within the individual to estimate the effect. Reduced statistical power might have contributed to previous heterogeneous findings regarding cognitive well-being. Using more appropriate random effect within between models (REWB; see Bell, Fairbrother \& Jones, 2016) we will not only examine differences between individuals who have permanent or fixed-term contracts, but also be able to take a detailed look at whether the employment contract type change itself has a causal effect on affective and cognitive well-being. We assume that because of the shorter time scale of emotions elicited by contract type changes, measures of affective well-being might be more suitable to examine subjective well-being and to display the effects of contract type change. In particular, we expect to observe an accumulation of negative emotions due to the already discussed increased job strain and the worse working conditions. A fixed-term contract should thus primarily go along with higher frequencies of experienced sadness, fear and anger, accompanied by a reduction of self-reported happiness. Furthermore, we are able to examine the direction of these effects by investigating subsamples of participants who changed from fixed-term to permanent employment and vice versa. The effects are expected to be negative when an employee changes from a permanent to a fixed- 
term contract, and positive when changing from fixed-term to permanent. According to the results from previous longitudinal studies on cognitive well-being (Bardasi \& Francesconi, 2004; De Cuyper \& De Witte, 2006), no significant relationships with cognitive well-being are expected.

\section{Methods}

\section{Data}

To investigate the effects of fixed-term employment on affective well-being, data from the SOEP (see Goebel, Grabka, Liebig, Kroh, Richter, Schröder \& Schupp, 2019), a longitudinal and representative national survey that includes data from 30,000 respondents living in 11,000 private households in Germany, is analyzed. In 2007, the SOEP integrated affective well-being measures into the questionnaire by adding questions regarding the frequency of experiences of four basic emotions during the previous four weeks as valid measurements of everyday emotional experiences (Schimmack et al., 2008). These emotions are assessed on an annual basis, which allows for a 10-wave sample of the SOEP data (until 2016). Cognitive well-being in the SOEP is measured by capturing the general life satisfaction with a single question. To be included in the study sample, and to examine a transition between permanent and fixed-term contracts (or vise a versa), respondents must have participated in the SOEP at least twice. Two different measurement points are the minimum requirements necessary for forwarding to a hybrid model analysis (see below). Thus, the "within effect" requires a change in the employment contract. To prevent the effects from being biased by a simultaneous change in employment status, only full-time workers are examined in this study. Furthermore, participants with any missing data in the main variables examined (contract type, affective and cognitive well-being), are excluded. This results in a total sample of 10,372 participants $(52,722$ observations) aged 18 to 78 years, of whom 1,964 recorded one or more changes from fixedterm to permanent employment or vice versa.

\section{Measures and Variables}

In the SOEP, affective well-being is captured by the frequency of different basic emotions during the previous four weeks. Since the 2007 SOEP, feelings of fear, anger, sadness and happiness have been recorded annually after the following question: "I will now read to you a number of feelings. Please indicate for each feeling how often or rarely you experienced this feeling in the last four weeks". The answers are entered on a five-level Likert scale, with the options "very rarely", "rarely", "occasionally", "often", "very often". Cognitive well-being (life satisfaction) is captured by the question: "How satisfied are you with your life, 
all things considered?" The answers are provided on an eleven-point rating scale ranging from 0 "completely dissatisfied" to 10 "completely satisfied". Fixed-term employment is captured through the question "Do you have a fixed-term or permanent employment contract?" Employment contract type is a nominal variable that includes every possible constellation at the time of the survey. The age variable is recorded by the year of birth. In the present study, these data are transformed into age values per point in time (of the wave), to be able to control the continuous change in age in the context of the following analyses.

We also incorporated the household income of the individual through the question: "If you look at the total income of all the members of your household, what is your monthly household income today?" In addition, we added the general health status as a covariate via the question: "How would you describe your current health?" This can be answered on a fivelevel Likert scale, with possible options of "very good", "good", "satisfactory", "bad" and "very bad". To reduce the possibility of effects due to a change in marital status we included dummy variables for marriage, divorce and widowhood as well as the number of children (continuous). We also added gender as an additional covariate, due to the possibility of including and controlling for time-constant variables in REWB modelling (which is not possible in standard (FE) regression). However, later models also include controls for job change as well as the concern of job security. While the former is captured by the question "have you changed jobs or started a new one since....?", with a simple yes or no answer, the latter is operationalized via the question "how concerned are you about the following issue: your job security?" The concern is then expressed on a 3-level scale, with the response options of "very concerned", "somewhat concerned" and "not concerned at all".

\section{Analytic Strategy}

Most previous studies on this topic have relied on FE regressions, which in statistical terms is an over-simplification of what is going on in longitudinal data. FE models control for time-constant unobserved heterogeneity (e.g. personality traits), by relying solely on withinperson variation (Brüderl, 2010; Krause \& Urban, 2013). Furthermore, the estimation of a within effect enables the possibility of identifying causal relations, because only changes within the individual are taken into account. FE modelling assumes that in a population the strength of an effect of $X$ on $Y$ has one (constant) true value (B), which is the most common value of a normal distribution of "(b)" (Krause \& Urban, 2013). In other words, FE models assume homogeneity in the within effects (a similar starting point and trajectory for each individual), which is unlikely to be true in complex longitudinal social data and can therefore lead to biased estimates and an inappropriate model fit (Bell et al., 2016). By adding random intercepts and 
slopes to a model, the assumption of homogeneity is dropped and the variances and covariances of the within effects are allowed to vary across individuals. Standard random effects models on the other hand, when being compared with FE models, have difficulties in correctly estimating within effects, since they do not fully control for time-constant unobserved heterogeneity (Bell et al., 2016). A main advantage of random effects models over FE models is that they enable the modelling of heterogeneous effects. Thus, in order to estimate the effects of fixed-term employment on cognitive and affective well-being we decided to compute REWB models (also known as hybrid models) for longitudinal data (see Allison, 2009; Bell et al., 2016; Krause \& Urban, 2013).

REWB models are effectively random effect models in that they model heterogeneity within the parameter estimates and at the same time incorporate the advantages known from fixed modelling (Bell et al., 2016). REWB models are multi-level models that distinguish between within (level 1) and between (level 2) effects. By computing REWB models, we gain unbiased estimates of within-person effects (e.g., the effect of a change in contract type on the dependent variable), estimates of between-person effects (e.g., the difference on the dependent variable between fixed-term and permanent workers), as well as the possibility to control and interpret the heterogeneity of the effect by adding random intercepts and slopes. Of note is that a between effect in these models cannot indicate causality because they only represent the mean difference (between groups) over all measurement points. More importantly, by controlling for such between effects in REWB models one receives an unbiased estimate of within effects (similar to estimates in FE models). To be more specific, the betweenperson employment contract change estimator in the present analyses tests whether employees with a fixed-term contract at some timepoint show differences in affective and cognitive well-being compared to employees with a permanent contract. In other words, individuals who differ by one unit on the independent variable (in this case a dummy variable with the value 1 for fixed-term work and 0 for permanent work) also differ by a certain amount on the dependent variable.

Of greater importance for an interpretation of causal effects in longitudinal data are the within effects. Similar to FE models, a within effect estimator only uses the within variance of each individual to test whether the employee's affective and cognitive well-being changes over time when the type of contract is changed. Thus, if the same individual changes one unit on the independent variable of the employment contract (from temporary to permanent or vice versa), their value on the dependent variable changes by a certain amount. Furthermore, only REWB models allow for the possibility of including a random intercept and random slopes to 
control for random effects and thus allow the level 1 (within) estimators to vary between individuals.

To control for further contextual effects, we included a fairly standard set of control variables in our analyses: the age of the participant, dummy variables for the marital status, the gender, the number of children, the general health and the household income, each of them divided into between and within effects (except gender). The dependent variables of the affective and cognitive well-being scales are strictly speaking ordinal scales but are considered as cardinal scales for the calculation of the models (similar to current state of research, see Clark, Diener, Georgellis \& Lucas, 2008; Ferrer-i-Carbonell, 2005; Ferrer-i-Carbonell \& Frijters, 2004; Kristoffersen, 2010). The nominal variable of employment contract change is dummycoded such that permanent workers are the reference group.

Equation 1 illustrates the final REWB model that is applied in the subsequent analyses for all five dependent variables (affective well-being: fear, anger, sadness and happiness; cognitive well-being: life satisfaction).

\section{Equation 1: REWB model}

Level 1: $Y_{t i}=\beta_{0 i}+\beta_{1 i} * \operatorname{contract}(\text { within })_{t i}+\beta_{2 i} *$ net hh income $(\text { within })_{t i}+\beta_{3 i} *$ age $(\text { within })_{t i}+\beta_{4 i} *$ health(within) $)_{t i}+\beta_{5 i} *$ married(within $)_{t i}+\beta_{6 i} * \operatorname{divorced}(\text { within })_{t i}+\beta_{7 i} *$ widowed(within) $)_{t i}+\beta_{8 i} *$ children(within $)_{t i}+e_{t i}$

Level 2: $\beta_{0 i}=\gamma_{00}+\gamma_{01} * \operatorname{contract}(\text { between })_{i}+\gamma_{02} *$ net hh income $(\text { between })_{i}+\gamma_{03} *$ age $(\text { between })_{i}+$

$\gamma_{04} *$ health(between $)_{i}+\gamma_{05} *$ married(between $)_{i}+\gamma_{06} *$ divorced (between $)_{i}+\gamma_{07} *$ widowed $(\text { between })_{i}+$

$\gamma_{08} *$ children (between $)_{i}+\gamma_{09} *$ gender $_{i}+u_{0 i}$

$\beta_{1 i}=\gamma_{10}+u_{1 i}$

$\beta_{2 i}=\gamma_{20}$

$\beta_{3 i}=\gamma_{30}$

$\beta_{4 i}=\gamma_{40}$

$\beta_{5 i}=\gamma_{50}$

$\beta_{6 i}=\gamma_{60}$

$\beta_{7 i}=\gamma_{70}$

$\beta_{8 i}=\gamma_{80}$

$\beta_{9 i}=\gamma_{90}$

r $u_{0 i}, u_{1 i}$

$t=$ timepoints $; i=$ individual; $\beta_{0 i}=$ intercept; $\beta_{1 i}$ to $\beta_{9 i}=$ beta coefficient to be estimated for each variable in the model; $e_{t i}=$ error term that varies across timepoints and individuals; $\gamma_{00}=$ Constant ;

$u_{0 i}=$ error term that varies across individuals; $\beta_{1-9}=$ predictor trajectory; $r_{u_{0 i}, u_{1 i}}=$ correlation of random intercept and slope.

Data are analysed according to the following strategy: First, Model 1 is computed, where the effect of fixed-term employment is separated in its within and between parts. To examine the hypothesis regarding the direction of these effects (a change from fixed-term to permanent has a positive impact on affective well-being, while the opposite change has a negative one) and to gain a deeper insight into the effects directly related to contract change, two further models are computed: Model 2 examines the direct impact of a change from fixedterm to permanent employment on affective and cognitive well-being, while Model 3 
investigates the opposite direction of change. To do so, Model 2 and 3 are tested for subgroups of the SOEP sample which include only the participants who changed from permanent to fixed-term contract, as well as all individuals with a permanent job as a reference group (Model 3, $n=9,458$ of whom 796 changed from permanent to fixed-term), or the participants who changed from fixed-term contract to permanent contract combined with all fixed-term workers (Model 2, $\mathrm{n}=1,531$ of whom 1,168 changed from fixed-term to permanent employment). Between effects in Model 2 and 3 compare persons with a change in contract type with persons reporting no change in contract type. The within effects are designed to directly examine whether the direction of contract change affects affective and cognitive wellbeing at the within-person level. These models only incorporate the data from the year prior to the change and the one immediately after.

An additional Model 4 is computed to analyse the robustness of the effects and a possible moderator effect by adding job change as a further control variable to Model 1 as well as an interaction term between the job change and the change in contract type as further predictors. Because mediator effects of job security have been reported in the literature (e.g., Dawson et al., 2017), a further model is computed that controls for a possible mediating effect of job security on the affective and cognitive well-being measures (Model 5). Preliminary analyses revealed that fixed-term contracts significantly lower job security $(\beta=-0.2241, S E=$ $0.01632, p<0.001$, see Table 6 ). Thus, to control for likely effects of job security on the dependent variables, effect terms for this variable are added to the equation of Model 4 for all full-time working participants, resulting in Model 5.

All models include a random intercept as well as a random slope of the contract type within effect (see equation 1). Whether the assumption of random slopes is appropriate for the present data can be tested by means of a Wald-z test, which is true for nearly all tested models. This indicates that the variances indeed differ between persons and that it should also be accompanied by improved measures of goodness of fit. Goodness of fit can be examined using, for example, the Akaike Information Criterion (AIC). AIC is a quantitative heuristic based on the deviance measure of the ML metric that can be used to compare different models. AIC incorporates a term for the number of free parameters that are estimated and thus penalizes a higher model complexity in model comparison. Smaller values of AIC suggest a better model fit.

\section{Results}

To ensure the readability of the paper, all tables are presented exclusively in the Appendix. Table 1 shows the estimates obtained from Model 1 on the sample of all SOEP 
full-time working participants for the measures of affective and cognitive well-being. Most of the predictors reveal significant effects on the dependent variables. In particular, in support of our initial hypothesis, differences in employment contract type have an effect on the frequency of fear and sadness experiences, and also on life satisfaction.

Thus, having a fixed-term contract in the SOEP sample goes along with higher frequencies of self-reported fear $(\beta=0.1061701, S E=0.027353, p<0.001)$, sadness $(\beta=$ $0.0842489, S E=0.0284944, p=0.003)$, and with a reduction in life satisfaction $(\beta=-$ $0.1320404, S E=0.0455575, p=0.003$ ). Looking at the within effects, additional significant impacts on fear and sadness are observed. This indicates that changes in the contract type increase the frequency of self-reported fear $(\beta=0.0499356, S E=0.0187694, p=0.008)$ and sadness $(\beta=0.0664376$, SE $=0.0210038, p=0.002)$, but not of life satisfaction $(\beta=$ $0.0081462, S E=0.0309916, p=0.746)$. Regarding happiness or anger measures, no significant effect of contract type is visible.

These associations for fear and sadness remained significant in Models 2 and 3 (see Table 2 and 3), but the direction of these effects gets clearer. Changes from permanent to fixed-term contracts go along with higher values of self-reported fear $(\beta=0.0685365, S E=$ $0.0311371, p=0.028)$ and sadness $(\beta=0.0912654, S E=0.0359847, p=0.011)$ at the withinperson level (Table 2, Model 2). A change from fixed-term to permanent contract instead leads to significant reductions in fear $(\beta=-0.0879808, S E=0.0285332, p=0.002)$ and sadness $(\beta$ $=-0.0641402, S E=0.0316372, p=0.043)$, and a significant increase in reported life satisfaction $(\beta=0.0916619, S E=0.0461247, p=0.047$; see Table 3 , Model 3).

\section{Moderator effect of job change?}

The addition of job change in Model 4 further improves the model. Both within and between effect estimators of job change reveal significant effects on some of the dependent variables (Table 4). However, no significant moderator effect of job change becomes visible, neither in cognitive nor affective well-being (as would be indicated by a significant job change ${ }^{*}$ change of contract type interaction). The within effects of contract type on fear $(\beta=$ $0.0418803, S E=0.0198727, p=0.035)$ and sadness $(\beta=0.0678389, S E=0.0222841, p=$ 0.002 ) remain significant and thus should be seen as being relatively robust in the SOEP sample of full-time workers. The between effects of contract type on life satisfaction $(\beta=-$ $0.038057, S E=0.04962, p=0.443)$ as well as on sadness $(\beta=0.0550644$, $S E=0.0311026$, $p=0.077$ ) are no longer significant. 
Mediator effect of job security (Model 5)

Even though job security has significant between and within effects on all five variables of affective and cognitive well-being (Table 5 ), only the within effect of contract type on the frequency of sadness remains significant $(\beta=0.0563472, S E=0.0222911, p=$ 0.011). The within and between effects of contract type on the frequency of fear are no longer significant. This reveals that a substantial portion of the variance in frequency of fear is explained by the concern of potential job loss. As concerns about job losses themselves are increased by fixed-term employment (see Table 6), we thus identify a strong mediating effect of job security on the relationship between fixed-term employment and the frequency of fear. When controlling for job security in Model 5 , the between effect of contract type on the frequency of anger becomes significant $(\beta=-0.0973923, S E=0.0316423, p=0.002)$.

\section{Discussion}

The results mainly support our initial assumptions. As expected, the type of contract, whether it is fixed-term or permanent, impacts affective well-being and thus indicates psychological effects on subjective well-being. These effects are visible as between effects that indicate differences between groups of persons with different employment contracts, but also, and more importantly, that can be shown to be directly related to a change of contract type (as becomes evident from the significant within effects). Finding and reporting these latter effects thus goes beyond previous results in the literature, which only revealed small to nonexistent within effects on subjective (cognitive) well-being (Bardasi \& Francesconi, 2004; De Cuyper \& De Witte, 2006; De Cuyper et al., 2008; Hünefeld \& Köper, 2016; Dawson et al., 2017). Thus, first results of the present study show the differential effects of contract type change on affective or cognitive well-being.

Regarding affective well-being, two further results emerge: Measurements of fear and sadness depend on the type of contract and change in parallel to changes in contract type. In a more general view, when all full-time workers are considered in Model 1, contract change is associated with a significant increase in self-reported fear and sadness at the individual level, even after controlling for job change in Model 4. The estimates of Models 2 and 3 reveal the robustness of these effects in smaller subsamples, while at the same time allowing a more detailed look at this pattern: The effect of contract change on fear and sadness is mainly driven by employees who change from permanent to fixed-term contracts (Model 2; see Table 2). Effects of permanent to fixed-term contract change show the same direction. In addition, the reverse change in contracts (from fixed-term to permanent in Model 3 points to an effect that 
is recognised from "getting a permanent position", which is associated with a reduction in the frequency of fear and sadness experiences. While the question regarding affective well-being has not directly been examined so far, these results relate to the theoretical assumption of lower job strain and distress when having a permanent position (De Cuyper et al., 2008). A plausible explanation for the effects on fear and sadness experiences could also be worse working conditions as well as shorter notice periods (Booth et al., 2002; Brehmer \& Seifert, 2008). Furthermore, one could assume that these feelings are not only caused by poorer working conditions, but that a feeling of helplessness can develop. An employee could feel at the mercy of difficult circumstances, as most likely it would not have been his or her preferred choice to sign a temporary contract, but rather a choice made because of the lack of alternatives. The uncertain future coupled with unsatisfactory working conditions could lead to a feeling of helplessness as might be evident in higher experiences of fear and sadness.

Examining the life satisfaction results confirms our initial methodological assumptions: Between effects of fixed-term work are observed in Models 1 and 3, but no robust within effect (i.e. effect of contract type change) is found, except for the smaller subsample of individuals who changed from fixed-term to permanent contracts in Model 2 (see discussion below). As such, the data for life satisfaction replicate the well-being literature, with weak effects between fixed-term and permanent workers and no clear effect of contract type change (Bardasi \& Francesconi, 2004; De Cuyper \& De Witte, 2006; De Cuyper et al., 2008; Dawson et al., 2017). Hence, in the German SOEP the measures of affective and cognitive well-being dissociate. One possible explanation for this could be that when judging their life satisfaction compared to evaluating specific affective experiences, people rely on different sources (Diener et al., 2004). For example, some participants take affective information into account when judging life satisfaction, while others tend to focus on different aspects (Oishi, Schimmack \& Diener., 2001). But even if the emotional part of well-being is considered, Kuppens and colleagues (2008) showed that the experience of positive emotions affects the judgment on life satisfaction twice as much as negative affects do. In the present results, only contract-related effects on negative emotions are visible. This result might further add to the discussion that the measure of life satisfaction mirrors only long-term effects on well-being (De Cuyper \& De Witte, 2006; Sverke, Hellgren \& Näswall, 2002). Given the present data, it seems more likely that only measures of affective well-being, with their more immediate time-scale, map those effects of contract type change on subjective well-being. Additionally, it seems likely that because affective well-being can be differentiated into positive and negative affect, these measures are more valid for this research question (see von Scheve et al., 2017; Schimmack, 2008). None of the present models revealed a within effect on happiness. Thus, a huge advantage of the 
present study is the differentiation between positive and negative affect in the measures of affective well-being which enabled us to capture the effects on negative emotions.

The between effects on life satisfaction in Models 1 and 3 have a negative indicator which corresponds to lower cognitive well-being in fixed-term workers (cf. De Cuyper et al., 2008; Dawson et al., 2017; Hünefeld \& Köper, 2016). However, this effect disappears when the model additionally controls for job change, as in Model 4 . We observed no moderator effect of job change (no significant interaction between job change and contract change in Models 4 and 5 on any of the well-being measures). A moderator effect would have indicated differential effects in fixed-term and permanent workers when contract type change is also accompanied by a change in workplace. Thus, given the present data, workplace and/or job change cannot explain the effects of contract type change on fear and sadness experiences, nor on life satisfaction. Independent of its relation to contract type, the inclusion of job change in Model 4 revealed that it also leads to a higher frequency of fear and happiness, as well as a lower frequency of anger.

The inclusion of concern about job security as a control variable in Model 5 has no effect on the direction or significance of the contract type change effect on sadness, which is a further indicator for the robustness of these effects. However, frequency of fear is no longer significant, suggesting that this effect was caused by an increase in the concern about job security, which seems to be associated with a temporary contract (e.g. Dawson et al., 2017; De Cuyper et al., 2008). Job security itself predicts significant proportions of variance in all five dependent measures: Lower measures of job security are associated with enhanced selfreported fear, sadness and anger, and lower experiences of happiness and a reduction of life satisfaction both as between and within effects. This result replicates, and regarding the affective well-being measures extends, our knowledge about the important, mediating, effect job security has on affective and cognitive wellbeing (De Cuyper et al., 2008; Dawson et al., 2017; Giesselmann et al., 2017, Booth et al., 2002). Although job security is not the main focus of the present examination, this pattern and its role as a mediator help to elucidate the present results of fixed-term employment. Previous studies showed that job security explains psychological effects of temporary workers (Dawson et al., 2017; Hünefeld \& Köper, 2016). The present result confirms this relationship for self-reported fear. But job security does not explain, or mediate, the effect of fixed-term contracts on self-reported sadness. Thus, above and beyond the variance explained by job change and job security, the frequency of sadness experiences is increased in relation to fixed-term contracts. 
Of some interest is that a within effect on life satisfaction is only revealed when the direction of contract change is taken into consideration. Changing from a permanent to fixedterm job has no (within) effect on life satisfaction (see Bardasi \& Francesconi, 2004; Green \& Haywood, 2011 for similar longitudinal effects). By contrast, changing from fixed-term to permanent contracts is shown in the subsample examined with Model 2 to increase life satisfaction. Finding a permanent position is seemingly related to (finally) enhance the cognitive well-being (and also to reduce experiences of fear and sadness). This might refer to the positive effects of contract change (the 'bridge to permanent' metaphor; cf. Booth et al., 2002; Rigotti \& Mohr, 2017) and is also in line with the predictions derived from the theoretical models (e.g. De Witte \& Näswall, 2003; De Cuyper et al., 2008) where fixed-term workers are considered peripheral workers (and thus a change leads to a change in status within the labour market, with all its beneficial effects). The effect on life satisfaction is particularly interesting, as no other model revealed this relationship with contract type change. Model 2 is based on the smallest subsample (of individuals changing from fixed-term to permanent contracts and of individuals already having a fixed-term contract) and the computations are restricted to only the year before and after the change (also true for Model 3). Thus, Model 2 would be expected to have the lowest statistical power to reveal such a within effect. We would again like to point to the advantages of REWB models to reveal such 'smaller' effects, and the obvious necessity also to examine the direction of contract change to be able to document this relationship. By contrast, changing from a permanent to a fixed-term contract does not impact life satisfaction. A possible explanation, which might be addressed in future research, could be the heterogeneity of the desire to change from a permanent to a fixed-term contract. It seems plausible that the change might have occurred either as a result of a wish to change jobs or because of a dismissal by the employer. If a change of work is desired by the employee, this could have a positive effect on life satisfaction, regardless of the immediate affective consequences of a fixed-term contract. However, if the reason for the change to a fixed-term contract was dismissal by the previous employer, this change could have a negative impact on life satisfaction, as no cognitive decision was made about the job change and the worker was forced to look for a new job.

The initially expected increases in the frequency of anger and decrease of self-reported happiness have not been observed. None of the models showed any direct effect of a change in the contract type on anger or happiness. While this has not been predicted, such a result points to the advantage of the availability of four different positive and negative measures of affective well-being in the German SOEP. This allows separate analysis for the different aspects of affective well-being and might be related to the difference between approach and avoidance emotions (see Davidson, 1998). While fear and sadness can be considered 
avoidance emotions, anger and happiness are associated with approach behaviour. Interestingly, the latter show no consistent effects in the present analysis. It thus seems likely that some relation to motivation and behaviour tendencies exist, triggered by fixed-term employments, which are in need of future examination. Inspection of Model 5 reveals that the null effects are not related to the measurements of self-reported anger and happiness themselves. While no relationship with contract type change is revealed, job security has strong relationships with all four measures of affective well-being. The only significant effects contract type has on self-reported happiness and anger are between effects in Model 3 (reduced happiness) and Model 5 (lower anger), which relate to group differences between fixed-term and permanent workers in these models.

\section{Limitations}

The examined sample only comprised full-time workers, thus heterogeneities due to part-time work cannot have contributed to the present results. This also implies that the effects found in this study only apply to full-time employees. It is possible that these results may be similar for fixed-term part-time and mini job contracts. However, further research is needed in order to test these effects under different circumstances. The sample sizes in the SOEP of individuals with part-time and mini job contracts may be too small to compute the REWB model with many control variables.

A second limitation of this study is the lack of control for the duration of the effects of contract type change by testing a lag structure in these models, which should be addressed in future research. Still, the results provide strong evidence for a connection between the fixed-term employment contract and an increase of experiencing negative emotions. However, one further limitation is related to the measurement of the affective well-being scales themselves: The measures of affective well-being ask participants about the frequency of experiencing these four emotions during the previous four weeks before the survey. Thus, as the survey is not temporarily related to the date of contract change, it seems likely that it does not capture all experienced emotions that are elicited by the contract change. Still, we believe that the decoupling of these time intervals rather leads to underestimating the true effects on affective well-being - if they start, as defined, immediately after an emotional event which is not necessarily in close relation to the date of the survey.

\section{Conclusion}

As fixed-term employment contracts are becoming increasingly popular in Germany and throughout Europe, it is important to investigate various psychological effects on the 
employees affected. In contrast to previous longitudinal studies that focused on the cognitive aspect of well-being, the SOEP's affective well-being scales and its four emotions measures provide another, more detailed insight into the day-to-day emotional experiences of temporary workers. The results of this analysis suggest that temporary workers' self-reported frequencies of fear and sadness experiences increase even though cognitive well-being (or happiness) is hardly affected. While the concern of job security significantly impacts the affective well-being of the temporary workers, it cannot not fully mask the negative affective consequences of fixedterm work on the experience of fear and sadness. While self-reported fear is mediated by the concern of job security, the increased frequency of sadness experiences is only related to contract type change itself. In particular, detailed analyses revealed that a change from permanent to temporary contracts increases sadness and the reverse change towards a permanent contract reduces self-reported sadness.

The effects on fear and sadness are visible on the between- but also, and more importantly, on the within person level. The results indicate that REWB models which consider between and within effects are effective in overcoming previous heterogeneities in the literature that are often based on improbable assumptions. The measures of affective wellbeing in the SOEP seem appropriate to examine psychological (affective) consequences on a short temporal scale in relation to temporary work, while intermediate, or longer lasting, negative effects on life satisfaction are not clearly visible in these data. Even though it can be functional to experience different (negative) emotions in relation to contract type changes (since this is linked to an adequate behavior in a particular situation), sustained experiences are certainly unhealthy and dysfunctional, influencing overall quality of life (Diener et al., 2004). Because the results provide strong evidence that an impact of contract type change on affective well-being, and in particular experienced sadness, exists, future research is asked to identify further moderators to reduce the psychological cost for the individual.

\section{Authors Note}

The data was made available by the German Institute for Economic Research (DIW Berlin). Neither the original collectors of the data, nor the archive, bear any responsibility for the analysis and presentations in this paper.

\section{Declaration of conflicting interests}

The authors declare no potential conflict of interest with respect to the research, authorship and publication of this article. 


\section{References}

Allison, P. D. (2009). Fixed effects regression models (Vol. 160). SAGE publications.

Amlinger-Chatterjee, M. (2016). Psychische Gesundheit in der Arbeitswelt- Atypische

Arbeitszeiten. Berlin: Bundesanstalt für Arbeitsschutz und Arbeitsmedizin.

Amuedo-Dorantes, C. (2000). Work transitions into and out of involuntary temporary employment in a segmented market: evidence from Spain. ILR Review, 53(2), 309-325.

Atkinson, J. (1984). Manpower strategies for flexible organizations. Personnel Management, 16(8), 28-31.

Bardasi, E., \& Francesconi, M. (2004). The impact of atypical employment on individual wellbeing: evidence from a panel of British workers. Social science \& medicine, 58(9), 1671-1688.

Becker, G. S. (1993). Nobel lecture: The economic way of looking at behavior. Journal of political economy, 101(3), 385-409.

Bell, A., Fairbrother, M., \& Jones, K. (2016). Fixed and Random effects models: making an informed choice. Working Paper.

Booth, A. L., Francesconi, M., \& Frank, J. (2002). Temporary jobs: stepping stones or dead ends?. The economic journal, 112(480), F189-F213.

Boyce, A. S., Ryan, A. M., Imus, A. L., \& Morgeson, F. P. (2007). "Temporary worker, permanent loser?" A model of the stigmatization of temporary workers. Journal of Management, 33(1), 5-29.

Brehmer, W. \& Seifert, H. (2008). Sind atypische Beschäftigungsverhältnisse prekär? Eine empirische Analyse sozialer Risiken. Journal for Labour Market Research, 41(4), 501531.

Brüderl, J. (2010). Kausalanalyse mit Paneldaten. In C. Wolf \& H. Best, Handbuch der sozialwissenschaftlichen Datenanalyse (pp. 963-994). Wiesbaden: VS Verlag für Sozialwissenschaften.

Clark, A. E., Diener, E., Georgellis, Y., \& Lucas, R. E. (2008). Lags and leads in life satisfaction: A test of the baseline hypothesis. The Economic Journal, 118(529), 222243.

Chadi, A., \& Hetschko, C. (2015). Flexibilization without hesitation? Temporary contracts and job satisfaction. Oxford Economic Papers, 68(1), 217-237.

Crößmann, A., Günther, L., Marder-Puch, K. (2017). Qualität der Arbeit-Geld verdienen und was sonst noch zählt. Wiesbaden: Selbstverlag.

Davidson, R.J. (1998). Affective Style and Affective Disorders: Perspectives from Affective Neuroscience. Cognition and Emotion, 12(3), 307-330

Dawson, C., Veliziotis, M., \& Hopkins, B. (2017). Temporary employment, job satisfaction and subjective well-being. Economic and industrial democracy, 38(1), 69-98. 
De Cuyper, N., \& De Witte, H. (2006). The impact of job insecurity and contract type on attitudes, well-being and behavioural reports: A psychological contract perspective. Journal of Occupational and Organizational Psychology, 79(3), 395-409.

De Cuyper, N., De Jong, J., De Witte, H., Isaksson, K., Rigotti, T., \& Schalk, R. (2008). Literature review of theory and research on the psychological impact of temporary employment: Towards a conceptual model. International Journal of Management Reviews, 10(1), 25-51.

De Cuyper, N., Notelaers, G., \& De Witte, H. (2009). Transitioning between temporary and permanent employment: A two-wave study on the entrapment, the stepping stone and the selection hypothesis. Journal of occupational and organizational Psychology, 82(1), 67-88.

De Witte, H., \& Näswall, K. (2003). Objective vs subjective job insecurity: Consequences of temporary work for job satisfaction and organizational commitment in four European countries. Economic and industrial democracy, 24(2), 149-188.

Deutscher Bundestag. (2017). Kleine Anfrage. Drucksache, 18/11608. Berlin: Deutscher Bundestag.

Diener, E. (1984). Subjective well-being. Psychological bulletin, 95(3), 542-575.

Diener, E., Scollon, C. N., \& Lucas, R. E. (2004). The evolving concept of subjective wellbeing: The multifaceted nature of happiness. Advanced in Cell Aging and Gerontology, 15,187-219.

Ehrhardt, J. J., Saris, W. E., \& Veenhoven, R. (2000). Stability of life-satisfaction over time. Journal of Happiness Studies, 1(2), 177-205.

Ferrer-i-Carbonell, A. (2005). Income and well-being: an empirical analysis of the comparison income effect. Journal of Public Economics, 89(5-6), 997-1019.

Ferrer-i-Carbonell, A., \& Frijters, P. (2004). How important is methodology for the estimates of the determinants of happiness? The Economic Journal, 114, 641-659.

Frijda, N.H (1999). Emotions and hedonic experience. In: Kahneman, D., Diener, E., Schwarz, N. (Eds.), Well-being: The Foundations of Hedonic Psychology (pp. 190210). New York, US: Russell Sage Foundation.

Fujita, F., \& Diener, E. (2005). Life satisfaction set point: stability and change. Journal of personality and social psychology, 88(1), 158-164.

Giesecke, J. (2009). Socio-economic risks of atypical employment relationships: Evidence from the German labour market. European Sociological Review, 25(6), 629-646.

Giesselmann, M., Staneva, M., Schupp, J., \& Richter, D. (2017). Arbeitsmarktposition und Arbeitszufriedenheit: quer-und längsschnittliche Befunde auf Basis des Sozioökonomischen Panels (SOEP) (N. 929). SOEPpapers on Multidisciplinary Panel Data Research. Berlin: Deutsches Institut für Wirtschaftsforschung. 
Goebel, J., Grabka, M. M., Liebig, S., Kroh, M., Richter, D., Schröder, C., \& Schupp, J. (2019). The german socio-economic panel (soep). Jahrbücher für Nationalökonomie und Statistik, 239(2), 345-360.

Goldberg, D. P., \& Hillier, V. F. (1979). A scaled version of the General Health Questionnaire. Psychological medicine, 9(1), 139-145.

Green, C. P., \& Heywood, J. S. (2011). Flexible contracts and subjective well-being. Economic Inquiry, 49(3), 716-729.

Hans-Böckler-Stiftung. (2017) Atypische Beschäftigung. Böckler Impuls. Ausgabe. 09. 2017 Available at: https://www.boeckler.de/wsi_5859.htm [28.2.2018].

Hünefeld, L. (2016). Psychische Gesundheit in der Arbeitswelt-Atypische Beschäftigung. Berlin: Berlin: Bundesanstalt für Arbeitsschutz und Arbeitsmedizin

Hünefeld, L., \& Köper, B. (2016). Fixed-term Employment and Job Insecurity (JI) as Risk factors for Mental Health. A Review of International Study Results. E-Journal of International and Comparative Labour Studies, 5(3).

Jahn, E. (2015). Don't worry, be flexible?-job satisfaction among flexible workers. Australian Journal of Labour Economics, 18(2), 147-190.

Kalleberg, A. L. (2011). Good jobs, bad jobs: The rise of polarized and precarious employment systems in the United States, 1970s-2000s. Russell Sage Foundation.

Krause, T. \& Urban, D. (2013) Panelanalysen mit Mehrebenenmodellen. Eine anwendungsorientierte Einführung. Stuttgart: Universität Stuttgart.

Kristoffersen, I. (2010). The metrics of subjective wellbeing: Cardinality, neutrality and additivity. Economic Record, 86(272), 98-123.

Kröll, C., \& Nüesch, S. (2017). The effects of flexible work practices on employee attitudes: evidence from a large-scale panel study in Germany. The International Journal of Human Resource Management, 1-21.

Kuppens, P., Realo, A., \& Diener, E. (2008). The role of positive and negative emotions in life satisfaction judgment across nations. Journal of personality and social psychology, 95(1), 66-75.

Odenthal, C. (2017). The Hartz myth - a closer look at Germany's labour market reforms. London: Centre for European Reform.

Oishi, S., Schimmack, U., \& Diener, E. (2001). Pleasures and subjective well-being. European Journal of Personality, 15(2), 153-167.

Richardson, S., Lester, L., \& Zhang, G. (2012). Are casual and contract terms of employment hazardous for mental health in Australia? Journal of Industrial Relations, 54(5), 557 $-578$. 
Rigotti, T., \& Mohr, G. (2017). German flexibility: loosening the reins without losing control. In Employment contracts and Well-being among European Workers (pp. 81-108). Routledge.

Scherer, S. (2009). The social consequences of insecure jobs. Social Indicators Research, 93(3), 527-547.

von Scheve, C., Esche, F., \& Schupp, J. (2017). The emotional timeline of unemployment: anticipation, reaction, and adaptation. Journal of Happiness Studies, 18(4), 1231-1254.

Schilling, O. (2006). Development of life satisfaction in old age: Another view on the" Paradox". Social Indicators Research, 75(2), 241-271.

Schimmack, U. (2008). Measuring wellbeing in the SOEP. SOEP papers on multidisciplinary panel data research, Berlin, Paper 145.

Schimmack, U., \& Lucas, R. E. (2006). Marriage Matters Spousal Similarity in Life Satisfaction (No. 623). DIW Discussion Papers.

Schimmack, U., \& Oishi, S. (2005). The influence of chronically and temporarily accessible information on life satisfaction judgments. Journal of personality and social psychology, 89(3), 395-407.

Schimmack, U., Schupp, J., \& Wagner, G. G. (2008). The influence of environment and personality on the affective and cognitive component of subjective well-being. Social indicators research, 89(1), 41-60.

Socio-Economic Panel (SOEP), data for years 1984-2016, version 33.1, SOEP, 2018, doi: 10.5684/soep.v33.1.

Schwarz, N., \& Clore, G. L. (1983). Mood, misattribution, and judgments of well-being: informative and directive functions of affective states. Journal of personality and social psychology, 45(3), 513-523.

Silla, I., Gracia, F. J., \& Peiró, J. M. (2005). Job insecurity and health-related outcomes among different types of temporary workers. Economic and Industrial Democracy, 26(1), 89-117.

Sumner, L. W. (1996). Welfare, happiness, and ethics. Clarendon Press.

Sverke, M., Hellgren, J. and Näswall, K. (2002). No security: a meta-analysis and review of job insecurity and its consequences. Journal of Occupational Health Psychology, 7(3), 242-264.

Vacas-Soriano, C. (2015), Recent developments in temporary employment: Employment growth, wages and transitions, Dublin, Ireland: Eurofound.

Virtanen, M., Kivimäki, M., Joensuu, M., Virtanen, P., Elovainio, M., \& Vahtera, J. (2005). Temporary employment and health: a review. International journal of epidemiology, 34(3), 610-622. 
Voßemer, J., Gebel, M., Täht, K., Unt, M., Högberg, B., \& Strandh, M. (2018). The effects of unemployment and insecure jobs on well-being and health: The moderating role of labor market policies. Social Indicators Research, 138(3), 1229-1257.

Winkelmann, L., \& Winkelmann, R. (1998). Why are the unemployed so unhappy? Evidence from panel data. Economica, 65(257), 1-15.

Zeytinoglu, I., \& Cooke, G. (2005). Non-standard work and benefits: has anything changed since the Wallace Report?. Relations Industrielles/Industrial Relations, 60(1), 29-63.

Zeytinoglu, I., \& Muteshi, J. (2000). Gender, race and class dimensions of nonstandard work. Relations Industrielles/Industrial Relations, 55(1), 133-167. 
Table 1: Estimates of Model 1 of all fulltime working participants

\begin{tabular}{|c|c|c|c|c|c|}
\hline & $\begin{array}{l}\text { (1) } \\
\text { Fear }\end{array}$ & $\begin{array}{c}(2) \\
\text { Sadness }\end{array}$ & $\begin{array}{c}\text { (3) } \\
\text { Happiness }\end{array}$ & $\begin{array}{c}\text { (4) } \\
\text { Anger }\end{array}$ & $\begin{array}{c}(5) \\
\text { Life } \\
\text { Satisfaction }\end{array}$ \\
\hline Contract type within & $\begin{array}{c}0.050^{\star \star \star} \\
(0.019)\end{array}$ & $\begin{array}{c}0.066^{\star * *} \\
(0.021)\end{array}$ & $\begin{array}{c}-0.011 \\
(0.016)\end{array}$ & $\begin{array}{l}-0.032 \\
(0.021)\end{array}$ & $\begin{array}{c}-0.008 \\
(0.031)\end{array}$ \\
\hline Contract type between & $\begin{array}{c}0.106^{\star * *} \\
(0.027)\end{array}$ & $\begin{array}{c}0.084^{\star * *} \\
(0.028)\end{array}$ & $\begin{array}{c}-0.013 \\
(0.024)\end{array}$ & $\begin{array}{l}-0.030 \\
(0.029)\end{array}$ & $\begin{array}{c}-0.132^{\star * *} \\
(0.045)\end{array}$ \\
\hline Gender & $\begin{array}{c}0.336^{\star \star *} \\
(0.013)\end{array}$ & $\begin{array}{c}0.342^{\star \star \star} \\
(0.014)\end{array}$ & $\begin{array}{c}0.065^{\star \star \star} \\
(0.012)\end{array}$ & $\begin{array}{c}0.083^{\star \star \star} \\
(0.014)\end{array}$ & $\begin{array}{c}0.066^{\star \star \star} \\
(0.022)\end{array}$ \\
\hline Age within & $\begin{array}{c}0.016^{\star * *} \\
(0.003)\end{array}$ & $\begin{array}{l}-0.005 \\
(0.004)\end{array}$ & $\begin{array}{c}0.021^{* * *} \\
(0.003)\end{array}$ & $\begin{array}{c}-0.019^{* \star *} \\
(0.004)\end{array}$ & $\begin{array}{c}0.035^{\star * *} \\
(0.005)\end{array}$ \\
\hline Age between & $\begin{array}{c}-0.054^{* * *} \\
(0.008)\end{array}$ & $\begin{array}{c}-0.065^{\star * *} \\
(0.008)\end{array}$ & $\begin{array}{c}-0.110^{* * *} \\
(0.007)\end{array}$ & $\begin{array}{c}-0.143^{\star * *} \\
(0.008)\end{array}$ & $\begin{array}{l}0.027^{* *} \\
(0.013)\end{array}$ \\
\hline Married within & $\begin{array}{c}0.009 \\
(0.023)\end{array}$ & $\begin{array}{c}0.021 \\
(0.025)\end{array}$ & $\begin{array}{c}0.054^{\star * *} \\
(0.020)\end{array}$ & $\begin{array}{l}-0.028 \\
(0.025)\end{array}$ & $\begin{array}{l}0.061^{*} \\
(0.035)\end{array}$ \\
\hline Married between & $\begin{array}{c}0.026 \\
(0.019)\end{array}$ & $\begin{array}{l}-0.031 \\
(0.020)\end{array}$ & $\begin{array}{c}0.203^{* * *} \\
(0.017)\end{array}$ & $\begin{array}{c}0.024 \\
(0.021)\end{array}$ & $\begin{array}{c}0.190^{\star * *} \\
(0.032)\end{array}$ \\
\hline Child within & $\begin{array}{l}-0.012 \\
(0.008)\end{array}$ & $\begin{array}{l}-0.020^{* *} \\
(0.009)\end{array}$ & $\begin{array}{l}-0.011 \\
(0.007)\end{array}$ & $\begin{array}{c}0.043^{* * *} \\
(0.009)\end{array}$ & $\begin{array}{c}0.003 \\
(0.012)\end{array}$ \\
\hline Child between & $\begin{array}{c}-0.004 \\
(0.008)\end{array}$ & $\begin{array}{c}0.011 \\
(0.008)\end{array}$ & $\begin{array}{c}-0.032^{* * *} \\
(0.007)\end{array}$ & $\begin{array}{c}0.030^{* * *} \\
(0.008)\end{array}$ & $\begin{array}{c}-0.011 \\
(0.013)\end{array}$ \\
\hline Health within & $\begin{array}{c}0.169^{* \star *} \\
(0.006)\end{array}$ & $\begin{array}{c}0.179^{\star * *} \\
(0.006)\end{array}$ & $\begin{array}{c}-0.140^{\star \star *} \\
(0.005)\end{array}$ & $\begin{array}{c}0.142^{\star \star *} \\
(0.006)\end{array}$ & $\begin{array}{c}-0.428^{\star \star *} \\
(0.009)\end{array}$ \\
\hline Health between & $\begin{array}{c}0.346^{* \star *} \\
(0.009)\end{array}$ & $\begin{array}{c}0.394^{* * *} \\
(0.010)\end{array}$ & $\begin{array}{c}-0.304^{* * *} \\
(0.008)\end{array}$ & $\begin{array}{c}0.401^{* * *} \\
(0.010)\end{array}$ & $\begin{array}{c}-1.001^{* * *} \\
(0.015)\end{array}$ \\
\hline Divorced within & $\begin{array}{c}0.282^{* * *} \\
(0.085)\end{array}$ & $\begin{array}{c}0.794^{\star \star *} \\
(0.095)\end{array}$ & $\begin{array}{c}-0.373^{\star * *} \\
(0.075)\end{array}$ & $\begin{array}{c}0.099 \\
(0.095)\end{array}$ & $\begin{array}{c}-0.328^{\star \star} \\
(0.131)\end{array}$ \\
\hline Divorced between & $\begin{array}{l}-0.009 \\
(0.063)\end{array}$ & $\begin{array}{c}0.195^{\star \star \star} \\
(0.065)\end{array}$ & $\begin{array}{l}-0.055 \\
(0.056)\end{array}$ & $\begin{array}{c}-0.136^{\star *} \\
(0.067)\end{array}$ & $\begin{array}{c}0.041 \\
(0.105)\end{array}$ \\
\hline Widowed within & $\begin{array}{l}-0.028 \\
(0.033)\end{array}$ & $\begin{array}{l}-0.061 \\
(0.037)\end{array}$ & $\begin{array}{c}0.143^{* * *} \\
(0.029)\end{array}$ & $\begin{array}{c}-0.097^{\star \star *} \\
(0.037)\end{array}$ & $\begin{array}{c}0.231^{* \star *} \\
(0.051)\end{array}$ \\
\hline Widowed between & $\begin{array}{l}-0.004 \\
(0.027)\end{array}$ & $\begin{array}{c}0.031 \\
(0.028)\end{array}$ & $\begin{array}{c}0.091^{* * *} \\
(0.024)\end{array}$ & $\begin{array}{l}-0.003 \\
(0.028)\end{array}$ & $\begin{array}{c}0.015 \\
(0.044)\end{array}$ \\
\hline $\mathrm{HH}$ income within & $\begin{array}{c}-0.000^{* * *} \\
(0.000)\end{array}$ & $\begin{array}{c}-0.000^{\star * *} \\
(0.000)\end{array}$ & $\begin{array}{l}0.000^{* *} \\
(0.000)\end{array}$ & $\begin{array}{l}-0.000 \\
(0.000)\end{array}$ & $\begin{array}{c}0.000^{\star * *} \\
(0.000)\end{array}$ \\
\hline $\mathrm{HH}$ income between & $\begin{array}{c}-0.000^{\star * \star} \\
(0.000)\end{array}$ & $\begin{array}{c}-0.000^{\star \star *} \\
(0.000)\end{array}$ & $\begin{array}{c}0.000^{\star \star \star} \\
(0.000)\end{array}$ & $\begin{array}{l}-0.000 \\
(0.000)\end{array}$ & $\begin{array}{c}0.000^{\star \star *} \\
(0.000)\end{array}$ \\
\hline Constant & $\begin{array}{c}0.533^{\star \star *} \\
(0.035)\end{array}$ & $\begin{array}{c}0.909^{\star * *} \\
(0.036)\end{array}$ & $\begin{array}{c}4.059^{\star * *} \\
(0.031)\end{array}$ & $\begin{array}{c}1.788^{\star \star *} \\
(0.037)\end{array}$ & $\begin{array}{c}9.174^{\star \star \star} \\
(0.057)\end{array}$ \\
\hline \multicolumn{6}{|l|}{ Random effects } \\
\hline Contract type within & $\begin{array}{c}0.371^{* * *} \\
(0.028)\end{array}$ & $\begin{array}{c}0.406^{\star * *} \\
(0.031)\end{array}$ & $\begin{array}{c}0.296^{\star \star *} \\
(0.025)\end{array}$ & $\begin{array}{c}0.375^{\star \star *} \\
(0.032)\end{array}$ & $\begin{array}{c}0.715^{\star \star \star} \\
(0.038)\end{array}$ \\
\hline Constant & $\begin{array}{c}0.525^{\star * *} \\
(0.005)\end{array}$ & $\begin{array}{c}0.522^{\star \star \star} \\
(0.005)\end{array}$ & $\begin{array}{c}0.474^{* * *} \\
(0.004)\end{array}$ & $\begin{array}{c}0.543^{* \star *} \\
(0.005)\end{array}$ & $\begin{array}{c}0.892^{* \star *} \\
(0.008)\end{array}$ \\
\hline $\begin{array}{l}\text { Correlation between } \\
\text { constant and contract } \\
\text { type within }\end{array}$ & $\begin{array}{l}0.113^{* *} \\
(0.056)\end{array}$ & $\begin{array}{c}0.039 \\
(0.060)\end{array}$ & $\begin{array}{c}0.070 \\
(0.065)\end{array}$ & $\begin{array}{c}0.046 \\
(0.064)\end{array}$ & $\begin{array}{c}0.008 \\
(0.049)\end{array}$ \\
\hline $\begin{array}{l}\text { Observations } \\
\text { Individuals } \\
\text { AIC }\end{array}$ & $\begin{array}{c}52722 \\
10372 \\
120303.6\end{array}$ & $\begin{array}{c}52129 \\
10372 \\
129126.0\end{array}$ & $\begin{array}{c}52745 \\
10372 \\
107206.4\end{array}$ & $\begin{array}{c}52761 \\
10372 \\
131092.4\end{array}$ & $\begin{array}{c}51896 \\
10370 \\
164973.1\end{array}$ \\
\hline
\end{tabular}

Standard errors are in parenthesis, ${ }^{\star \star *} \mathrm{p}<0.01,{ }^{\star *} \mathrm{p}<0.05$, contract type $=$ fixed term or permanent contract coded as a dummy variable with permanent workers as reference group (0), $\mathrm{HH}$ income=Household income. 
Table 2: Estimates of Model 2 to examine effects of a change in working conditions (from fixed term to permanent employment contracts, F2P)

\begin{tabular}{|c|c|c|c|c|c|}
\hline & $\begin{array}{l}\text { (1) } \\
\text { Fear }\end{array}$ & $\begin{array}{c}(2) \\
\text { Sadness }\end{array}$ & $\begin{array}{c}(3) \\
\text { Happiness }\end{array}$ & $\begin{array}{c}(4) \\
\text { Anger }\end{array}$ & $\begin{array}{c}(5) \\
\text { Life } \\
\text { Satisfaction }\end{array}$ \\
\hline Change F2P within & $\begin{array}{c}-0.088^{\star \star \star} \\
(0.029)\end{array}$ & $\begin{array}{c}-0.064^{\star \star} \\
(0.032)\end{array}$ & $\begin{array}{c}0.034 \\
(0.026)\end{array}$ & $\begin{array}{l}-0.015 \\
(0.033)\end{array}$ & $\begin{array}{l}0.092^{\star \star} \\
(0.046)\end{array}$ \\
\hline Change F2P between & $\begin{array}{c}0.058 \\
(0.100)\end{array}$ & $\begin{array}{c}0.140 \\
(0.099)\end{array}$ & $\begin{array}{c}-0.129 \\
(0.080)\end{array}$ & $\begin{array}{c}0.091 \\
(0.099)\end{array}$ & $\begin{array}{c}0.069 \\
(0.154)\end{array}$ \\
\hline Gender & $\begin{array}{c}0.348^{\star \star *} \\
(0.041)\end{array}$ & $\begin{array}{c}0.428^{\star * *} \\
(0.040)\end{array}$ & $\begin{array}{l}0.071^{* *} \\
(0.033)\end{array}$ & $\begin{array}{c}0.050 \\
(0.040)\end{array}$ & $\begin{array}{c}0.043 \\
(0.063)\end{array}$ \\
\hline Age within & $\begin{array}{c}0.003 \\
(0.018)\end{array}$ & $\begin{array}{c}-0.043^{* *} \\
(0.019)\end{array}$ & $\begin{array}{l}0.032^{* *} \\
(0.016)\end{array}$ & $\begin{array}{c}0.006 \\
(0.019)\end{array}$ & $\begin{array}{c}0.033 \\
(0.029)\end{array}$ \\
\hline Age between & $\begin{array}{c}-0.013 \\
(0.027)\end{array}$ & $\begin{array}{l}-0.005 \\
(0.026)\end{array}$ & $\begin{array}{c}-0.130^{\star * *} \\
(0.021)\end{array}$ & $\begin{array}{c}-0.1799^{* * *} \\
(0.027)\end{array}$ & $\begin{array}{c}-0.054 \\
(0.041)\end{array}$ \\
\hline Married within & $\begin{array}{c}0.041 \\
(0.080)\end{array}$ & $\begin{array}{c}0.028 \\
(0.087)\end{array}$ & $\begin{array}{l}-0.050 \\
(0.072)\end{array}$ & $\begin{array}{c}0.037 \\
(0.088)\end{array}$ & $\begin{array}{c}0.019 \\
(0.128)\end{array}$ \\
\hline Married between & $\begin{array}{l}-0.033 \\
(0.062)\end{array}$ & $\begin{array}{l}-0.109^{\star} \\
(0.061)\end{array}$ & $\begin{array}{c}0.255^{\star * *} \\
(0.049)\end{array}$ & $\begin{array}{l}0.108^{\star} \\
(0.061)\end{array}$ & $\begin{array}{c}0.311^{* * *} \\
(0.095)\end{array}$ \\
\hline Child within & $\begin{array}{c}-0.087^{* *} \\
(0.037)\end{array}$ & $\begin{array}{l}-0.031 \\
(0.040)\end{array}$ & $\begin{array}{l}0.076^{* *} \\
(0.033)\end{array}$ & $\begin{array}{l}-0.007 \\
(0.040)\end{array}$ & $\begin{array}{c}0.058 \\
(0.060)\end{array}$ \\
\hline Child between & $\begin{array}{c}-0.026 \\
(0.027)\end{array}$ & $\begin{array}{c}0.020 \\
(0.027)\end{array}$ & $\begin{array}{c}-0.021 \\
(0.021)\end{array}$ & $\begin{array}{l}0.044^{\star} \\
(0.027)\end{array}$ & $\begin{array}{c}-0.064 \\
(0.041)\end{array}$ \\
\hline Health within & $\begin{array}{c}0.145^{\star * *} \\
(0.023)\end{array}$ & $\begin{array}{c}0.206^{* * *} \\
(0.025)\end{array}$ & $\begin{array}{c}-0.176^{* * *} \\
(0.020)\end{array}$ & $\begin{array}{c}0.135^{\star \star *} \\
(0.025)\end{array}$ & $\begin{array}{c}-0.421^{* * *} \\
(0.036)\end{array}$ \\
\hline Health between & $\begin{array}{c}0.337^{* * *} \\
(0.033)\end{array}$ & $\begin{array}{c}0.462^{* * *} \\
(0.032)\end{array}$ & $\begin{array}{c}-0.351^{* * *} \\
(0.026)\end{array}$ & $\begin{array}{c}0.427^{* * *} \\
(0.033)\end{array}$ & $\begin{array}{c}-1.018^{* * *} \\
(0.050)\end{array}$ \\
\hline Divorced within & $\begin{array}{c}1.158 \\
(0.946)\end{array}$ & $\begin{array}{l}1.990^{* *} \\
(0.950)\end{array}$ & $\begin{array}{c}-1.685^{\star \star} \\
(0.770)\end{array}$ & $\begin{array}{c}-0.560 \\
(0.953)\end{array}$ & $\begin{array}{c}-1.168 \\
(1.466)\end{array}$ \\
\hline Divorced between & $\begin{array}{c}0.279 \\
(0.269)\end{array}$ & $\begin{array}{c}0.124 \\
(0.265)\end{array}$ & $\begin{array}{c}0.101 \\
(0.215)\end{array}$ & $\begin{array}{c}0.334 \\
(0.267)\end{array}$ & $\begin{array}{c}0.088 \\
(0.413)\end{array}$ \\
\hline Widowed within & $\begin{array}{c}-0.065 \\
(0.148)\end{array}$ & $\begin{array}{l}-0.245 \\
(0.160)\end{array}$ & $\begin{array}{l}-0.135 \\
(0.131)\end{array}$ & $\begin{array}{l}-0.164 \\
(0.161)\end{array}$ & $\begin{array}{c}0.231 \\
(0.236)\end{array}$ \\
\hline Widowed between & $\begin{array}{l}-0.128 \\
(0.098)\end{array}$ & $\begin{array}{l}-0.114 \\
(0.097)\end{array}$ & $\begin{array}{c}0.227^{\star \star \star} \\
(0.078)\end{array}$ & $\begin{array}{c}0.123 \\
(0.098)\end{array}$ & $\begin{array}{c}0.169 \\
(0.151)\end{array}$ \\
\hline $\mathrm{HH}$ income within & $\begin{array}{l}-0.000 \\
(0.000)\end{array}$ & $\begin{array}{l}-0.000 \\
(0.000)\end{array}$ & $\begin{array}{l}-0.000 \\
(0.000)\end{array}$ & $\begin{array}{c}0.000 \\
(0.000)\end{array}$ & $\begin{array}{c}0.000 \\
(0.000)\end{array}$ \\
\hline $\mathrm{HH}$ income between & $\begin{array}{c}-0.000 \\
(0.000)\end{array}$ & $\begin{array}{c}-0.000^{\star * *} \\
(0.000)\end{array}$ & $\begin{array}{c}0.000^{\star * *} \\
(0.000)\end{array}$ & $\begin{array}{l}-0.000 \\
(0.000)\end{array}$ & $\begin{array}{c}0.000^{* * *} \\
(0.000)\end{array}$ \\
\hline Constant & $\begin{array}{c}0.646^{* * *} \\
(0.113)\end{array}$ & $\begin{array}{c}0.723^{* * *} \\
(0.112)\end{array}$ & $\begin{array}{c}4.145^{* * *} \\
(0.090)\end{array}$ & $\begin{array}{c}1.671^{* * *} \\
(0.112)\end{array}$ & $\begin{array}{c}9.183^{* * *} \\
(0.174)\end{array}$ \\
\hline \multicolumn{6}{|l|}{ Random effects } \\
\hline Contract type within & $\begin{array}{c}0.130 \\
(0.160)\end{array}$ & $\begin{array}{c}0.093^{* * *} \\
(0.037)\end{array}$ & $\begin{array}{l}0.003 \\
(0.01)\end{array}$ & $\begin{array}{c}0.272^{* * *} \\
(0.094)\end{array}$ & $\begin{array}{c}0.172^{* * *} \\
(0.053)\end{array}$ \\
\hline Constant & $\begin{array}{c}0.603^{* * *} \\
(0.019)\end{array}$ & $\begin{array}{c}0.547^{* * *} \\
(0.019)\end{array}$ & $\begin{array}{c}0.432 \\
(0.019)\end{array}$ & $\begin{array}{c}0.554^{* * *} \\
(0.021)\end{array}$ & $\begin{array}{c}0.902^{* * *} \\
(0.030)\end{array}$ \\
\hline $\begin{array}{l}\text { Correlation between } \\
\text { constant and contract } \\
\text { type within }\end{array}$ & $\begin{array}{l}-0.590 \\
(0.748)\end{array}$ & $\begin{array}{l}-0.775 \\
(0.045)\end{array}$ & $\begin{array}{c}-0.982 \\
(0.002)\end{array}$ & $\begin{array}{l}-.0 .222 \\
(0.162)\end{array}$ & $\begin{array}{l}-0.995 \\
(0.001)\end{array}$ \\
\hline $\begin{array}{l}\text { Observations } \\
\text { Individuals }\end{array}$ & $\begin{array}{l}3646 \\
1531\end{array}$ & $\begin{array}{l}3650 \\
1531\end{array}$ & $\begin{array}{l}3648 \\
1531\end{array}$ & $\begin{array}{l}3650 \\
1531\end{array}$ & $\begin{array}{l}3609 \\
1528\end{array}$ \\
\hline $\mathrm{AIC}$ & 9522.824 & 8051.442 & 9579.045 & 9715.500 & 12280.860 \\
\hline
\end{tabular}

Standard errors are in parenthesis, ${ }^{* * *} p<0.01,{ }^{* *} p<0.05,1168$ Individuals reported 1242 changes from fixed-term to permanent contracts, $\mathrm{HH}$ income=Household income. 
Table 3: Estimates of Model 3 to examine effects of a change in working conditions (from permanent to fixed term employment contracts, P2F)

\begin{tabular}{|c|c|c|c|c|c|}
\hline & $\begin{array}{l}(1) \\
\text { Fear }\end{array}$ & $\begin{array}{c}(2) \\
\text { Sadness }\end{array}$ & $\begin{array}{c}(3) \\
\text { Happiness }\end{array}$ & $\begin{array}{c}(4) \\
\text { Anger }\end{array}$ & $\begin{array}{c}\text { (6) } \\
\text { Life } \\
\text { Satisfaction }\end{array}$ \\
\hline Change P2F within & $\begin{array}{l}0.069^{\star *} \\
(0.031)\end{array}$ & $\begin{array}{l}0.091^{\star *} \\
(0.036)\end{array}$ & $\begin{array}{c}-0.030 \\
(0.029)\end{array}$ & $\begin{array}{c}-0.064 \\
(0.036)\end{array}$ & $\begin{array}{c}0.058 \\
(0.056)\end{array}$ \\
\hline Change P2F between & $\begin{array}{c}0.276^{* * *} \\
(0.072)\end{array}$ & $\begin{array}{c}0.264^{* * *} \\
(0.076)\end{array}$ & $\begin{array}{c}-0.130^{* *} \\
(0.065)\end{array}$ & $\begin{array}{c}0.101 \\
(0.078)\end{array}$ & $\begin{array}{c}-0.237^{\star *} \\
(0.119)\end{array}$ \\
\hline Gender & $\begin{array}{c}0.325^{\star \star *} \\
(0.014)\end{array}$ & $\begin{array}{c}0.331^{* * *} \\
(0.014)\end{array}$ & $\begin{array}{c}0.059^{\star * *} \\
(0.013)\end{array}$ & $\begin{array}{c}0.075^{\star \star *} \\
(0.015)\end{array}$ & $\begin{array}{l}0.055^{\star *} \\
(0.023)\end{array}$ \\
\hline Age within & $\begin{array}{c}0.019^{\star * *} \\
(0.004)\end{array}$ & $\begin{array}{l}-0.004 \\
(0.004)\end{array}$ & $\begin{array}{c}0.019^{\star * *} \\
(0.003)\end{array}$ & $\begin{array}{c}-0.017^{\star * *} \\
(0.004)\end{array}$ & $\begin{array}{c}0.029^{* * *} \\
(0.006)\end{array}$ \\
\hline Age between & $\begin{array}{c}-0.054^{\star * *} \\
(0.008)\end{array}$ & $\begin{array}{c}-0.064^{\star * *} \\
(0.009)\end{array}$ & $\begin{array}{c}-0.109^{\star \star *} \\
(0.008)\end{array}$ & $\begin{array}{c}-0.140^{\star * *} \\
(0.009)\end{array}$ & $\begin{array}{c}0.046^{\star * *} \\
(0.014)\end{array}$ \\
\hline Married within & $\begin{array}{c}0.014 \\
(0.025)\end{array}$ & $\begin{array}{c}0.020 \\
(0.028)\end{array}$ & $\begin{array}{l}0.047^{* *} \\
(0.022)\end{array}$ & $\begin{array}{c}-0.032 \\
(0.028)\end{array}$ & $\begin{array}{l}0.070^{\star} \\
(0.038)\end{array}$ \\
\hline Married between & $\begin{array}{l}0.041^{* *} \\
(0.021)\end{array}$ & $\begin{array}{c}-0.013 \\
(0.021)\end{array}$ & $\begin{array}{c}0.195^{\star * *} \\
(0.019)\end{array}$ & $\begin{array}{c}0.024 \\
(0.022)\end{array}$ & $\begin{array}{c}0.165^{\star \star *} \\
(0.034)\end{array}$ \\
\hline Child within & $\begin{array}{l}-0.008 \\
(0.009)\end{array}$ & $\begin{array}{c}-0.022^{* *} \\
(0.010)\end{array}$ & $\begin{array}{l}-0.011 \\
(0.008)\end{array}$ & $\begin{array}{c}0.044^{* * *} \\
(0.010)\end{array}$ & $\begin{array}{c}0.000 \\
(0.013)\end{array}$ \\
\hline Child between & $\begin{array}{l}-0.006 \\
(0.008)\end{array}$ & $\begin{array}{c}0.008 \\
(0.008)\end{array}$ & $\begin{array}{c}-0.028^{* * *} \\
(0.007)\end{array}$ & $\begin{array}{c}0.028^{* * *} \\
(0.009)\end{array}$ & $\begin{array}{l}-0.003 \\
(0.013)\end{array}$ \\
\hline Health within & $\begin{array}{c}0.168^{\star * *} \\
(0.006)\end{array}$ & $\begin{array}{c}0.177^{* * *} \\
(0.007)\end{array}$ & $\begin{array}{c}-0.134^{\star * *} \\
(0.005)\end{array}$ & $\begin{array}{c}0.141^{* * *} \\
(0.007)\end{array}$ & $\begin{array}{c}-0.433^{\star * *} \\
(0.009)\end{array}$ \\
\hline Health between & $\begin{array}{c}0.347^{\star * *} \\
(0.010)\end{array}$ & $\begin{array}{c}0.393^{\star * *} \\
(0.010)\end{array}$ & $\begin{array}{c}-0.305^{\star \star *} \\
(0.009)\end{array}$ & $\begin{array}{c}0.402^{\star * *} \\
(0.010)\end{array}$ & $\begin{array}{c}-1.028^{\star * *} \\
(0.016)\end{array}$ \\
\hline Divorced within & $\begin{array}{c}0.260^{\star \star *} \\
(0.088)\end{array}$ & $\begin{array}{c}0.752^{\star \star \star} \\
(0.098)\end{array}$ & $\begin{array}{c}-0.361^{\star \star \star} \\
(0.077)\end{array}$ & $\begin{array}{c}0.114 \\
(0.099)\end{array}$ & $\begin{array}{c}-0.397^{\star \star \star} \\
(0.135)\end{array}$ \\
\hline Divorced between & $\begin{array}{l}-0.014 \\
(0.066)\end{array}$ & $\begin{array}{l}0.162^{\star \star} \\
(0.068)\end{array}$ & $\begin{array}{l}-0.039 \\
(0.059)\end{array}$ & $\begin{array}{c}-0.169^{\star *} \\
(0.070)\end{array}$ & $\begin{array}{c}-0.023 \\
(0.110)\end{array}$ \\
\hline Widowed within & $\begin{array}{c}-0.031 \\
(0.035)\end{array}$ & $\begin{array}{l}-0.056 \\
(0.039)\end{array}$ & $\begin{array}{c}0.141^{\star * *} \\
(0.031)\end{array}$ & $\begin{array}{c}-0.107^{\star \star \star *} \\
(0.039)\end{array}$ & $\begin{array}{c}0.247^{\star * *} \\
(0.054)\end{array}$ \\
\hline Widowed between & $\begin{array}{c}0.002 \\
(0.028)\end{array}$ & $\begin{array}{c}0.032 \\
(0.029)\end{array}$ & $\begin{array}{c}0.091^{* * *} \\
(0.025)\end{array}$ & $\begin{array}{l}-0.013 \\
(0.030)\end{array}$ & $\begin{array}{c}0.012 \\
(0.047)\end{array}$ \\
\hline $\mathrm{HH}$ income within & $\begin{array}{c}-0.000^{* * *} \\
(0.000)\end{array}$ & $\begin{array}{c}-0.000^{\star * \star} \\
(0.000)\end{array}$ & $\begin{array}{l}0.000^{* *} \\
(0.000)\end{array}$ & $\begin{array}{c}-0.000 \\
(0.000)\end{array}$ & $\begin{array}{c}0.000^{* * *} \\
(0.000)\end{array}$ \\
\hline $\mathrm{HH}$ income between & $\begin{array}{c}-0.000^{\star * *} \\
(0.000)\end{array}$ & $\begin{array}{c}-0.000^{\star * *} \\
(0.000)\end{array}$ & $\begin{array}{c}0.000^{\star \star \star} \\
(0.000)\end{array}$ & $\begin{array}{l}-0.000 \\
(0.000)\end{array}$ & $\begin{array}{c}0.000^{* * *} \\
(0.000)\end{array}$ \\
\hline Constant & $\begin{array}{c}0.539^{* * *} \\
(0.037)\end{array}$ & $\begin{array}{c}0.920^{* * *} \\
(0.038)\end{array}$ & $\begin{array}{c}4.066^{\star \star *} \\
(0.033)\end{array}$ & $\begin{array}{c}1.798^{* * *} \\
(0.039)\end{array}$ & $\begin{array}{c}9.242^{* * *} \\
(0.061)\end{array}$ \\
\hline \multicolumn{6}{|l|}{ Random effects } \\
\hline Contract type within & $\begin{array}{c}0.308^{* * *} \\
(0.059)\end{array}$ & $\begin{array}{c}0.407^{* * *} \\
(0.059)\end{array}$ & $\begin{array}{c}0.371^{* * *} \\
(0.043)\end{array}$ & $\begin{array}{c}0.434^{* * *} \\
(.057)\end{array}$ & $\begin{array}{c}0.898 \\
(0.065)\end{array}$ \\
\hline Constant & $\begin{array}{c}0.526^{* * *} \\
(0.010)\end{array}$ & $\begin{array}{c}0.527^{* * *} \\
(0.005)\end{array}$ & $\begin{array}{c}0.480^{\star * *} \\
(0.004)\end{array}$ & $\begin{array}{c}0.546^{* * *} \\
(0.006)\end{array}$ & $\begin{array}{c}0.900^{* * *} \\
(0.008)\end{array}$ \\
\hline Correlation between & $0.258^{* *}$ & 0.039 & 0.009 & -0.066 & -0.088 \\
\hline & $(0.123)$ & $(0.104)$ & $(0.094)$ & $(0.098)$ & $(0.069)$ \\
\hline $\begin{array}{l}\text { Observations } \\
\text { Individuals } \\
\text { AIC }\end{array}$ & $\begin{array}{c}47515 \\
9458 \\
107517.6\end{array}$ & $\begin{array}{c}47558 \\
9458 \\
117194.4\end{array}$ & $\begin{array}{c}47535 \\
9458 \\
95845.42\end{array}$ & $\begin{array}{c}47548 \\
9458 \\
117654.4\end{array}$ & $\begin{array}{c}46885 \\
9455 \\
147614.8\end{array}$ \\
\hline
\end{tabular}

Standard errors are in parenthesis, ${ }^{* \star *} p<0.01,{ }^{* \star} p<0.05,796$ Individuals reported 846 changes from permanent to fixed-term contracts, $\mathrm{HH}$ income=Household income. 
Table 4: Estimates of Model 1 of all fulltime working participants with control of a job change

\begin{tabular}{|c|c|c|c|c|c|}
\hline & $\begin{array}{l}\text { (1) } \\
\text { Fear }\end{array}$ & $\begin{array}{c}(2) \\
\text { Sadness }\end{array}$ & $\begin{array}{c}(3) \\
\text { Happiness }\end{array}$ & $\begin{array}{c}(4) \\
\text { Anger }\end{array}$ & $\begin{array}{c}(5) \\
\text { Life } \\
\text { Satisfaction }\end{array}$ \\
\hline Contract type within & $\begin{array}{l}0.042^{* \star} \\
(0.020)\end{array}$ & $\begin{array}{c}0.068^{* * *} \\
(0.022)\end{array}$ & $\begin{array}{l}-0.014 \\
(0.017)\end{array}$ & $\begin{array}{c}-0.027 \\
(0.022)\end{array}$ & $\begin{array}{c}-0.017 \\
(0.033)\end{array}$ \\
\hline Contract type between & $\begin{array}{l}0.064^{* *} \\
(0.030)\end{array}$ & $\begin{array}{c}0.055 \\
(0.031)\end{array}$ & $\begin{array}{l}-0.002 \\
(0.027)\end{array}$ & $\begin{array}{c}-0.059 \\
(0.032)\end{array}$ & $\begin{array}{c}-0.038 \\
(0.050)\end{array}$ \\
\hline Job change within & $\begin{array}{l}0.028^{* *} \\
(0.012)\end{array}$ & $\begin{array}{c}0.017 \\
(0.014)\end{array}$ & $\begin{array}{l}0.023^{* *} \\
(0.011)\end{array}$ & $\begin{array}{c}-0.094^{* * *} \\
(0.013)\end{array}$ & $\begin{array}{c}0.007 \\
(0.019)\end{array}$ \\
\hline Job change between & $\begin{array}{c}0.111^{* \star *} \\
(0.031)\end{array}$ & $\begin{array}{l}0.082^{* *} \\
(0.032)\end{array}$ & $\begin{array}{l}-0.023 \\
(0.027)\end{array}$ & $\begin{array}{l}0.070^{* *} \\
(0.033)\end{array}$ & $\begin{array}{c}-0.256^{* * *} \\
(0.051)\end{array}$ \\
\hline $\begin{array}{l}\text { Contract type } \\
\text { within*Job change } \\
\text { within }\end{array}$ & $\begin{array}{c}-0.007 \\
(0.045)\end{array}$ & $\begin{array}{c}-0.055 \\
(0.050)\end{array}$ & $\begin{array}{l}-0.033 \\
(0.039)\end{array}$ & $\begin{array}{c}0.046 \\
(0.049)\end{array}$ & $\begin{array}{c}0.037 \\
(0.071)\end{array}$ \\
\hline Gender & $\begin{array}{c}0.336^{* * *} \\
(0.013)\end{array}$ & $\begin{array}{c}0.342^{* * *} \\
(0.014)\end{array}$ & $\begin{array}{c}0.065^{\star * *} \\
(0.012)\end{array}$ & $\begin{array}{c}0.082^{* * *} \\
(0.014)\end{array}$ & $\begin{array}{c}0.067^{* * *} \\
(0.022)\end{array}$ \\
\hline Age within & $\begin{array}{c}0.016 * * * \\
(0.003)\end{array}$ & $\begin{array}{l}-0.006 \\
(0.004)\end{array}$ & $\begin{array}{c}0.022^{\star * *} \\
(0.003)\end{array}$ & $\begin{array}{c}-0.023^{\star * *} \\
(0.004)\end{array}$ & $\begin{array}{c}0.038^{* * *} \\
(0.005)\end{array}$ \\
\hline Age between & $\begin{array}{c}-0.046^{\star \star *} \\
(0.008)\end{array}$ & $\begin{array}{c}-0.060^{\star \star \star *} \\
(0.009)\end{array}$ & $\begin{array}{c}-0.112^{\star \star *} \\
(0.007)\end{array}$ & $\begin{array}{c}-0.138^{\star * *} \\
(0.009)\end{array}$ & $\begin{array}{c}0.012 \\
(0.014)\end{array}$ \\
\hline Married within & $\begin{array}{c}0.011 \\
(0.023)\end{array}$ & $\begin{array}{c}0.023 \\
(0.025)\end{array}$ & $\begin{array}{c}0.056^{\star * *} \\
(0.020)\end{array}$ & $\begin{array}{l}-0.036 \\
(0.025)\end{array}$ & $\begin{array}{l}0.069^{* *} \\
(0.035)\end{array}$ \\
\hline Married between & $\begin{array}{c}0.027 \\
(0.019)\end{array}$ & $\begin{array}{l}-0.029 \\
(0.020)\end{array}$ & $\begin{array}{c}0.203^{* * *} \\
(0.017)\end{array}$ & $\begin{array}{c}0.025 \\
(0.021)\end{array}$ & $\begin{array}{c}0.188^{* * *} \\
(0.033)\end{array}$ \\
\hline Child within & $\begin{array}{c}-0.012 \\
(0.008)\end{array}$ & $\begin{array}{c}-0.020^{* *} \\
(0.009)\end{array}$ & $\begin{array}{l}-0.011 \\
(0.007)\end{array}$ & $\begin{array}{c}0.043^{* * *} \\
(0.009)\end{array}$ & $\begin{array}{l}-0.001 \\
(0.012)\end{array}$ \\
\hline Child between & $\begin{array}{l}-0.004 \\
(0.008)\end{array}$ & $\begin{array}{c}0.011 \\
(0.008)\end{array}$ & $\begin{array}{c}-0.032^{\star * *} \\
(0.007)\end{array}$ & $\begin{array}{c}0.030^{\star * *} \\
(0.008)\end{array}$ & $\begin{array}{c}-0.011 \\
(0.013)\end{array}$ \\
\hline Health within & $\begin{array}{c}0.169^{* * *} \\
(0.006)\end{array}$ & $\begin{array}{c}0.179^{\star * *} \\
(0.006)\end{array}$ & $\begin{array}{c}-0.140^{\star \star * *} \\
(0.005)\end{array}$ & $\begin{array}{c}0.141^{\star * *} \\
(0.006)\end{array}$ & $\begin{array}{c}-0.438^{\star * *} \\
(0.009)\end{array}$ \\
\hline Health between & $\begin{array}{c}0.346^{* * *} \\
(0.009)\end{array}$ & $\begin{array}{c}0.393^{\star * *} \\
(0.010)\end{array}$ & $\begin{array}{c}-0.304^{\star * *} \\
(0.008)\end{array}$ & $\begin{array}{c}0.401^{* * *} \\
(0.010)\end{array}$ & $\begin{array}{c}-1.018^{\star * \star} \\
(0.016)\end{array}$ \\
\hline Divorced within & $\begin{array}{c}0.282^{* * *} \\
(0.085)\end{array}$ & $\begin{array}{c}0.795^{\star * *} \\
(0.095)\end{array}$ & $\begin{array}{c}-0.373^{\star * *} \\
(0.075)\end{array}$ & $\begin{array}{c}0.097 \\
(0.095)\end{array}$ & $\begin{array}{c}-0.421^{* * *} \\
(0.131)\end{array}$ \\
\hline Divorced between & $\begin{array}{l}-0.007 \\
(0.063)\end{array}$ & $\begin{array}{c}0.196^{\star * *} \\
(0.065)\end{array}$ & $\begin{array}{l}-0.056 \\
(0.056)\end{array}$ & $\begin{array}{c}-0.135^{\star *} \\
(0.067)\end{array}$ & $\begin{array}{l}-0.009 \\
(0.105)\end{array}$ \\
\hline Widowed within & $\begin{array}{l}-0.025 \\
(0.033)\end{array}$ & $\begin{array}{l}-0.060 \\
(0.037)\end{array}$ & $\begin{array}{c}0.145^{\star * *} \\
(0.029)\end{array}$ & $\begin{array}{c}-0.106^{\star * *} \\
(0.037)\end{array}$ & $\begin{array}{c}0.234^{* * *} \\
(0.051)\end{array}$ \\
\hline Widowed between & $\begin{array}{l}-0.004 \\
(0.027)\end{array}$ & $\begin{array}{c}0.031 \\
(0.028)\end{array}$ & $\begin{array}{c}0.091^{* * *} \\
(0.024)\end{array}$ & $\begin{array}{l}-0.003 \\
(0.028)\end{array}$ & $\begin{array}{c}0.014 \\
(0.045)\end{array}$ \\
\hline $\mathrm{HH}$ income within & $\begin{array}{c}-0.000^{* \star * *} \\
(0.000)\end{array}$ & $\begin{array}{c}-0.000^{\star * *} \\
(0.000)\end{array}$ & $\begin{array}{l}0.000^{* *} \\
(0.000)\end{array}$ & $\begin{array}{l}-0.000 \\
(0.000)\end{array}$ & $\begin{array}{c}0.000^{* * *} \\
(0.000)\end{array}$ \\
\hline $\mathrm{HH}$ income between & $\begin{array}{c}-0.000^{\star \star *} \\
(0.000)\end{array}$ & $\begin{array}{c}-0.000^{\star \star *} \\
(0.000)\end{array}$ & $\begin{array}{c}0.000^{\star \star \star} \\
(0.000)\end{array}$ & $\begin{array}{l}-0.000 \\
(0.000)\end{array}$ & $\begin{array}{c}0.000^{* \star *} \\
(0.000)\end{array}$ \\
\hline Constant & $\begin{array}{c}0.520^{\star * *} \\
(0.035)\end{array}$ & $\begin{array}{c}0.899^{* * *} \\
(0.036)\end{array}$ & $\begin{array}{c}4.062^{\star * \star} \\
(0.031)\end{array}$ & $\begin{array}{l}1.779 * * * \\
(0.037)\end{array}$ & $\begin{array}{c}9.238^{* * *} \\
(0.058)\end{array}$ \\
\hline \multicolumn{6}{|l|}{ Random effects } \\
\hline Contract type within & $\begin{array}{c}0.370^{\star * *} \\
(0.028)\end{array}$ & $\begin{array}{c}0.406^{* * *} \\
(0.031)\end{array}$ & $\begin{array}{c}0.295^{\star \star *} \\
(0.025)\end{array}$ & $\begin{array}{c}0.372^{\star * *} \\
(0.033)\end{array}$ & $\begin{array}{c}0.716^{* * *} \\
(0.040)\end{array}$ \\
\hline Constant & $\begin{array}{c}0.525^{\star * *} \\
(0.005)\end{array}$ & $\begin{array}{c}0.521^{* * *} \\
(0.005)\end{array}$ & $\begin{array}{c}0.473^{* * *} \\
(0.005)\end{array}$ & $\begin{array}{c}0.543^{* * *} \\
(0.005)\end{array}$ & $\begin{array}{c}0.901^{* * *} \\
(0.008)\end{array}$ \\
\hline $\begin{array}{l}\text { Correlation between } \\
\text { constant and contract } \\
\text { type within }\end{array}$ & $\begin{array}{l}0.115^{\star \star} \\
(0.056)\end{array}$ & $\begin{array}{c}0.037 \\
(0.060)\end{array}$ & $\begin{array}{c}0.071 \\
(0.065)\end{array}$ & $\begin{array}{c}0.044 \\
(0.065)\end{array}$ & $\begin{array}{c}0.013 \\
(0.049)\end{array}$ \\
\hline $\begin{array}{l}\text { Observations } \\
\text { Individuals } \\
\text { AIC }\end{array}$ & $\begin{array}{c}52722 \\
10372 \\
120291.0\end{array}$ & $\begin{array}{c}52129 \\
10372 \\
129123.0\end{array}$ & $\begin{array}{c}52745 \\
10372 \\
107206.2\end{array}$ & $\begin{array}{c}52761 \\
10372 \\
131044.9\end{array}$ & $\begin{array}{c}51965 \\
10370 \\
164953.6\end{array}$ \\
\hline
\end{tabular}

Standard errors are in parenthesis, ${ }^{\star \star *} p<0.01,{ }^{\star \star}{ }^{*} p<0.05$, contract type $=$ fixed term or permanent contract coded as a dummy variable with permanent workers as reference group $(0), \mathrm{HH}$ income $=$ Household income. 
Table 5: Estimates of Model 1 of all fulltime working participants with control of a job change and concern of job security

\begin{tabular}{|c|c|c|c|c|c|}
\hline & $\begin{array}{l}(1) \\
\text { Fear }\end{array}$ & $\begin{array}{c}(2) \\
\text { Sadness }\end{array}$ & $\begin{array}{c}\text { (3) } \\
\text { Happiness }\end{array}$ & $\begin{array}{c}(4) \\
\text { Anger }\end{array}$ & $\begin{array}{c}(5) \\
\text { Life } \\
\text { Satisfaction }\end{array}$ \\
\hline Contract type within & $\begin{array}{c}0.027 \\
(0.020)\end{array}$ & $\begin{array}{l}0.056^{\star *} \\
(0.022)\end{array}$ & $\begin{array}{l}-0.009 \\
(0.017)\end{array}$ & $\begin{array}{l}-0.039 \\
(0.022)\end{array}$ & $\begin{array}{c}0.012 \\
(0.033)\end{array}$ \\
\hline Contract type between & $\begin{array}{c}0.012 \\
(0.030)\end{array}$ & $\begin{array}{c}0.014 \\
(0.031)\end{array}$ & $\begin{array}{c}0.028 \\
(0.027)\end{array}$ & $\begin{array}{c}-0.097^{* \star *} \\
(0.032)\end{array}$ & $\begin{array}{c}0.085 \\
(0.048)\end{array}$ \\
\hline Job change within & $\begin{array}{l}0.029^{* *} \\
(0.012)\end{array}$ & $\begin{array}{c}0.018 \\
(0.014)\end{array}$ & $\begin{array}{l}0.023^{\star *} \\
(0.011)\end{array}$ & $\begin{array}{c}-0.094^{* * *} \\
(0.013)\end{array}$ & $\begin{array}{l}0.006 \\
(0.019)\end{array}$ \\
\hline Job change between & $\begin{array}{l}0.091^{* * *} \\
(0.030)\end{array}$ & $\begin{array}{l}0.066^{\star *} \\
(0.032)\end{array}$ & $\begin{array}{l}-0.012 \\
(0.027)\end{array}$ & $\begin{array}{c}0.055 \\
(0.032)\end{array}$ & $\begin{array}{l}-0.211^{* * *} \\
(0.050)\end{array}$ \\
\hline $\begin{array}{l}\text { Contract type within* } \\
\text { Job change within }\end{array}$ & $\begin{array}{l}-0.012 \\
(0.045)\end{array}$ & $\begin{array}{l}-0.059 \\
(0.050)\end{array}$ & $\begin{array}{l}-0.031 \\
(0.039)\end{array}$ & $\begin{array}{c}0.042 \\
(0.049)\end{array}$ & $\begin{array}{c}0.048 \\
(0.071)\end{array}$ \\
\hline Job security within & $\begin{array}{l}-0.191^{* * *} \\
(0.011)\end{array}$ & $\begin{array}{l}-0.154^{\star \star \star} \\
(0.011)\end{array}$ & $\begin{array}{l}0.111^{\star * *} \\
(0.010)\end{array}$ & $\begin{array}{l}-0.141^{* * *} \\
(0.012)\end{array}$ & $\begin{array}{l}0.456^{\star * *} \\
(0.018)\end{array}$ \\
\hline Job security between & $\begin{array}{c}-0.064^{* * *} \\
(0.005)\end{array}$ & $\begin{array}{l}-0.052^{* * *} \\
(0.006)\end{array}$ & $\begin{array}{c}0.023^{* * *} \\
(0.005)\end{array}$ & $\begin{array}{c}-0.052^{\star * *} \\
(0.006)\end{array}$ & $\begin{array}{c}0.128^{* * *} \\
(0.008)\end{array}$ \\
\hline Gender & $\begin{array}{c}0.343^{* \star *} \\
(0.013)\end{array}$ & $\begin{array}{c}0.347^{\star \star *} \\
(0.013)\end{array}$ & $\begin{array}{c}0.062^{\star \star \star} \\
(0.012)\end{array}$ & $\begin{array}{c}0.087^{\star \star \star} \\
(0.014)\end{array}$ & $\begin{array}{l}0.052^{\star \star} \\
(0.021)\end{array}$ \\
\hline Age within & $\begin{array}{l}0.019^{* * *} \\
(0.003)\end{array}$ & $\begin{array}{l}-0.003 \\
(0.004)\end{array}$ & $\begin{array}{c}0.021^{* * *} \\
(0.003)\end{array}$ & $\begin{array}{c}-0.020^{* * *} \\
(0.004)\end{array}$ & $\begin{array}{l}0.031^{* * *} \\
(0.005)\end{array}$ \\
\hline Age between & $\begin{array}{l}-0.040^{* \star *} \\
(0.008)\end{array}$ & $\begin{array}{l}-0.055^{\star * *} \\
(0.008)\end{array}$ & $\begin{array}{c}-0.115^{\star * *} \\
(0.007)\end{array}$ & $\begin{array}{l}-0.133^{\star * *} \\
(0.009)\end{array}$ & $\begin{array}{c}-0.001 \\
(0.013)\end{array}$ \\
\hline Married within & $\begin{array}{c}0.010 \\
(0.023)\end{array}$ & $\begin{array}{c}0.022 \\
(0.025)\end{array}$ & $\begin{array}{c}0.056^{\star \star \star} \\
(0.020)\end{array}$ & $\begin{array}{c}-0.037 \\
(0.025)\end{array}$ & $\begin{array}{l}0.070^{\star *} \\
(0.035)\end{array}$ \\
\hline Married between & $\begin{array}{c}0.009 \\
(0.019)\end{array}$ & $\begin{array}{c}-0.044^{\star *} \\
(0.020)\end{array}$ & $\begin{array}{c}0.214^{\star * *} \\
(0.017)\end{array}$ & $\begin{array}{c}0.011 \\
(0.020)\end{array}$ & $\begin{array}{c}0.232^{* * *} \\
(0.032)\end{array}$ \\
\hline Child within & $\begin{array}{l}-0.011 \\
(0.008)\end{array}$ & $\begin{array}{c}-0.019^{* *} \\
(0.009)\end{array}$ & $\begin{array}{c}-0.011 \\
(0.007)\end{array}$ & $\begin{array}{c}0.043^{* * *} \\
(0.009)\end{array}$ & $\begin{array}{c}-0.001 \\
(0.012)\end{array}$ \\
\hline Child between & $\begin{array}{c}-0.007 \\
(0.008)\end{array}$ & $\begin{array}{c}0.008 \\
(0.008)\end{array}$ & $\begin{array}{c}-0.030^{* * *} \\
(0.007)\end{array}$ & $\begin{array}{c}0.028^{* * *} \\
(0.008)\end{array}$ & $\begin{array}{l}-0.003 \\
(0.012)\end{array}$ \\
\hline Health within & $\begin{array}{c}0.167^{* * *} \\
(0.006)\end{array}$ & $\begin{array}{c}0.177^{\star * *} \\
(0.006)\end{array}$ & $\begin{array}{c}-0.139^{* * *} \\
(0.005)\end{array}$ & $\begin{array}{c}0.139^{* * *} \\
(0.006)\end{array}$ & $\begin{array}{c}-0.433^{\star * *} \\
(0.009)\end{array}$ \\
\hline Health between & $\begin{array}{c}0.314^{* * *} \\
(0.009)\end{array}$ & $\begin{array}{c}0.368^{* * *} \\
(0.010)\end{array}$ & $\begin{array}{c}-0.286^{* * *} \\
(0.008)\end{array}$ & $\begin{array}{c}0.377^{* * *} \\
(0.010)\end{array}$ & $\begin{array}{c}-0.943^{\star \star *} \\
(0.015)\end{array}$ \\
\hline Divorced within & $\begin{array}{c}0.284^{* * *} \\
(0.085)\end{array}$ & $\begin{array}{c}0.796^{* * *} \\
(0.095)\end{array}$ & $\begin{array}{c}-0.373^{\star * *} \\
(0.075)\end{array}$ & $\begin{array}{c}0.099 \\
(0.095)\end{array}$ & $\begin{array}{c}-0.423^{\star * *} \\
(0.131)\end{array}$ \\
\hline Divorced between & $\begin{array}{l}-0.010 \\
(0.062)\end{array}$ & $\begin{array}{c}0.193^{\star \star *} \\
(0.064)\end{array}$ & $\begin{array}{l}-0.054 \\
(0.056)\end{array}$ & $\begin{array}{c}-0.137^{\star *} \\
(0.066)\end{array}$ & $\begin{array}{c}0.000 \\
(0.102)\end{array}$ \\
\hline Widowed within & $\begin{array}{l}-0.027 \\
(0.033)\end{array}$ & $\begin{array}{l}-0.061 \\
(0.037)\end{array}$ & $\begin{array}{c}0.146^{\star * *} \\
(0.029)\end{array}$ & $\begin{array}{c}-0.107^{* * *} \\
(0.037)\end{array}$ & $\begin{array}{c}0.237^{* * *} \\
(0.051)\end{array}$ \\
\hline Widowed between & $\begin{array}{l}-0.011 \\
(0.026)\end{array}$ & $\begin{array}{c}0.024 \\
(0.027)\end{array}$ & $\begin{array}{c}0.095^{\star * *} \\
(0.024)\end{array}$ & $\begin{array}{c}-0.009 \\
(0.028)\end{array}$ & $\begin{array}{c}0.032 \\
(0.043)\end{array}$ \\
\hline $\mathrm{HH}$ income within & $\begin{array}{c}-0.000^{* \star *} \\
(0.000)\end{array}$ & $\begin{array}{c}-0.000^{\star * *} \\
(0.000)\end{array}$ & $\begin{array}{l}0.000^{* *} \\
(0.000)\end{array}$ & $\begin{array}{l}-0.000 \\
(0.000)\end{array}$ & $\begin{array}{c}0.000^{* * *} \\
(0.000)\end{array}$ \\
\hline $\mathrm{HH}$ income between & $\begin{array}{l}-0.000 \\
(0.000)\end{array}$ & $\begin{array}{c}-0.000^{* * *} \\
(0.000)\end{array}$ & $\begin{array}{c}0.000^{* * *} \\
(0.000)\end{array}$ & $\begin{array}{l}0.000^{*} \\
(0.000)\end{array}$ & $\begin{array}{c}0.000^{* * *} \\
(0.000)\end{array}$ \\
\hline Constant & $\begin{array}{l}1.028^{* * *} \\
(0.045)\end{array}$ & $\begin{array}{c}1.309^{* * *} \\
(0.047)\end{array}$ & $\begin{array}{c}3.768^{\star * *} \\
(0.040)\end{array}$ & $\begin{array}{c}2.154^{\star * *} \\
(0.048)\end{array}$ & $\begin{array}{c}8.033^{\star * *} \\
(0.074)\end{array}$ \\
\hline Random effects & & & & & \\
\hline Contract type within & $\begin{array}{c}0.370^{* \star *} \\
(0.028)\end{array}$ & $\begin{array}{c}0.404^{* * *} \\
(0.032)\end{array}$ & $\begin{array}{c}0.294^{* * *} \\
(0.025)\end{array}$ & $\begin{array}{c}0.371^{* * *} \\
(0.032)\end{array}$ & $\begin{array}{c}0.711^{* * *} \\
(0.039)\end{array}$ \\
\hline Constant & $\begin{array}{c}0.514^{\star \star \star} \\
(0.006)\end{array}$ & $\begin{array}{c}0.514^{* * *} \\
(0.005)\end{array}$ & $\begin{array}{c}0.470^{\star \star \star} \\
(0.005)\end{array}$ & $\begin{array}{c}0.538^{\star \star \star} \\
(0.006)\end{array}$ & $\begin{array}{c}0.864^{\star \star *} \\
(0.009)\end{array}$ \\
\hline $\begin{array}{l}\text { Correlation between } \\
\text { constant and contract } \\
\text { type within }\end{array}$ & $\begin{array}{l}0.129^{* *} \\
(0.056)\end{array}$ & $\begin{array}{c}0.035 \\
(0.061)\end{array}$ & $\begin{array}{c}0.067 \\
(0.065)\end{array}$ & $\begin{array}{c}0.043 \\
(0.065)\end{array}$ & $\begin{array}{c}0.033 \\
(0.050)\end{array}$ \\
\hline $\begin{array}{l}\text { Observations } \\
\text { Individuals } \\
\text { AIC }\end{array}$ & $\begin{array}{c}52722 \\
10372 \\
119836.5 \\
\end{array}$ & $\begin{array}{c}52129 \\
10372 \\
128867.2 \\
\end{array}$ & $\begin{array}{c}52745 \\
10372 \\
107057.2 \\
\end{array}$ & $\begin{array}{c}52761 \\
10372 \\
130820.6 \\
\end{array}$ & $\begin{array}{c}51965 \\
10370 \\
164073.4 \\
\end{array}$ \\
\hline
\end{tabular}

Standard errors are in parenthesis, ${ }^{* \star *} \mathrm{p}<0.01,{ }^{* *} \mathrm{p}<0.05$, contract type $=$ fixed term or permanent contract coded as a dummy variable with permanent workers as reference group (0), $\mathrm{HH}$ income=Household income. 
Table 6: Estimates of all fulltime working participants with concern of job security as the dependent variable

\section{(1)}

Concern of

job security

\begin{tabular}{|c|c|}
\hline Contract type between & $\begin{array}{c}-0.271^{\star \star \star} \\
(0.025)\end{array}$ \\
\hline Contract type within & $\begin{array}{c}-0.224^{\star \star *} \\
(0.016)\end{array}$ \\
\hline Job change between & $\begin{array}{l}0.018^{* *} \\
(0.009)\end{array}$ \\
\hline Job change within & $\begin{array}{c}-0.099^{\star * *} \\
(0.025)\end{array}$ \\
\hline $\begin{array}{l}\text { Contract type within* } \\
\text { Job change within }\end{array}$ & $\begin{array}{l}-0.042 \\
(0.034)\end{array}$ \\
\hline Gender & $\begin{array}{c}0.032^{* * *} \\
(0.011)\end{array}$ \\
\hline Age within & $\begin{array}{l}0.065^{\star * *} \\
(0.003)\end{array}$ \\
\hline Age between & $\begin{array}{l}0.044^{* * *} \\
(0.007)\end{array}$ \\
\hline Married within & $\begin{array}{l}-0.027 \\
(0.016)\end{array}$ \\
\hline Married between & $\begin{array}{c}-0.111^{* \star *} \\
(0.016)\end{array}$ \\
\hline Child within & $\begin{array}{c}0.004 \\
(0.006)\end{array}$ \\
\hline Child between & $\begin{array}{c}-0.020^{* * *} \\
(0.006)\end{array}$ \\
\hline Health within & $\begin{array}{c}-0.040^{* \star *} \\
(0.004)\end{array}$ \\
\hline Health between & $\begin{array}{c}-0.167^{* \star *} \\
(0.008)\end{array}$ \\
\hline Divorced within & $\begin{array}{l}-0.010 \\
(0.060)\end{array}$ \\
\hline Divorced between & $\begin{array}{l}-0.053 \\
(0.052)\end{array}$ \\
\hline Widowed within & $\begin{array}{l}-0.031 \\
(0.023)\end{array}$ \\
\hline Widowed between & $\begin{array}{l}-0.050^{* *} \\
(0.022)\end{array}$ \\
\hline $\mathrm{HH}$ income within & $\begin{array}{l}0.000^{* *} \\
(0.000)\end{array}$ \\
\hline $\mathrm{HH}$ income between & $\begin{array}{l}0.000^{* * *} \\
(0.000)\end{array}$ \\
\hline Constant & $\begin{array}{c}2.715^{\star * *} \\
(0.029)\end{array}$ \\
\hline Random effects & \\
\hline contract type within & $\begin{array}{l}0.419^{* * *} \\
(0.016)\end{array}$ \\
\hline Constant & $\begin{array}{l}0.461^{* * *} \\
(0.009)\end{array}$ \\
\hline $\begin{array}{l}\text { Correlation between constant } \\
\text { and contract type within }\end{array}$ & $\begin{array}{c}0.039 \\
(0.041)\end{array}$ \\
\hline $\begin{array}{l}\text { Observations } \\
\text { Individuals }\end{array}$ & $\begin{array}{l}52018 \\
10372\end{array}$ \\
\hline
\end{tabular}

Standard errors are in parenthesis ${ }^{\star \star *} p<0.01,{ }^{\star *} p<0.05$, results on the concern of job security are negative due to the scale of the question, $\mathrm{HH}$ income=Household income. 